\title{
Adult Autism Subthreshold Spectrum (AdAS Spectrum): Validation of a questionnaire investigating subthreshold autism spectrum
}

\author{
L. Dell'Osso ${ }^{\text {a }}$, C. Gesi ${ }^{\text {a }}$, E. Massimetti ${ }^{\text {a }}$, I.M. Cremone ${ }^{\text {a }}$, M. Barbuti ${ }^{\text {a }}$, G. Maccariello ${ }^{\text {a }}$,
}

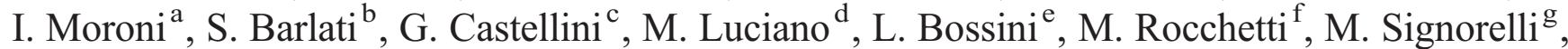

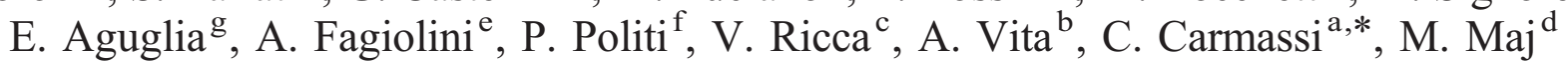

${ }^{\mathrm{a} D e p a r t m e n t ~ o f ~ C l i n i c a l ~ a n d ~ E x p e r i m e n t a l ~ M e d i c i n e, ~ U n i v e r s i t y ~ o f ~ P i s a, ~ P i s a, ~ I t a l y ~}$

${ }^{\mathrm{b}}$ Department of Clinical and Experimental Sciences, University of Brescia, Brescia, Italy

${ }^{\mathrm{c}}$ Department of Neuroscience, Psychology, Drug Research and Child Health, University of Florence, Florence, Italy

${ }^{\mathrm{d} D e p a r t m e n t ~ o f ~ P s y c h i a t r y, ~ U n i v e r s i t y ~ o f ~ N a p l e s ~ S U N, ~ N a p l e s, ~ I t a l y ~}$

${ }^{\mathrm{e}}$ Department of Mental Health and Department of Molecular Medicine, University of Siena, Siena, Italy

${ }^{\mathrm{f}}$ Department of Brain and Behavioral Sciences, University of Pavia, Pavia, Italy

${ }^{\mathrm{g}}$ Department of Clinical and Molecular Biomedicine, University of Catania, Catania, Italy

\begin{abstract}
Aim: Increasing literature has shown the usefulness of a dimensional approach to autism. The present study aimed to determine the psychometric properties of the Adult Autism Subthreshold Spectrum (AdAS Spectrum), a new questionnaire specifically tailored to assess subthreshold forms of autism spectrum disorder (ASD) in adulthood.

Methods: 102 adults endorsing at least one DSM-5 symptom criterion for ASD (ASDc), 143 adults diagnosed with a feeding and eating disorder (FED), and 160 subjects with no mental disorders (CTL), were recruited from 7 Italian University Departments of Psychiatry and administered the following: SCID-5, Autism-Spectrum Quotient (AQ), Ritvo Autism and Asperger Diagnostic Scale 14-item version (RAADS-14), and AdAS Spectrum. Results: The AdAS Spectrum demonstrated excellent internal consistency for the total score (Kuder-Richardson's coefficient=.964) as well as for five out of seven domains (all coefficients $>.80$ ) and sound test-retest reliability (ICC=.976). The total and domain AdAS Spectrum scores showed a moderate to strong $(>.50)$ positive correlation with one another and with the AQ and RAADS-14 total scores. ASDc subjects reported significantly higher AdAS Spectrum total scores than both FED $(p<.001)$ and CTL $(p<.001)$, and significantly higher scores on the Childhood/adolescence, Verbal communication, Empathy, Inflexibility and adherence to routine, and Restricted interests and rumination domains (all $p<.001$ ) than FED, while on all domains compared to CTL. CTL displayed significantly lower total and domain scores than FED (all $p<.001)$. A significant effect of gender emerged for the Hyper-and hyporeactivity to sensory input domain, with women showing higher scores than men $(p=.003)$. A Diagnosis* Gender interaction was also found for the Verbal communication ( $p=.019)$ and Empathy $(p=.023)$ domains. When splitting the ASDc in subjects with one symptom criterion $\left(\mathrm{ASD}_{1}\right)$ and those with a ASD, and the FED in subjects with no ASD symptom criteria $\left(\mathrm{FED}_{0}\right)$ and those with one $\mathrm{ASD}$ symptom criterion $\left(\mathrm{FED}_{1}\right)$, a gradient of severity in AdAS Spectrum scores from CTL subjects to ASD patients, across $\mathrm{FED}_{0}, \mathrm{ASD}_{1}, \mathrm{FED}_{1}$ was shown.

Conclusions: The AdAS Spectrum showed excellent internal consistency and test-retest reliability and strong convergent validity with alternative dimensional measures of ASD. The questionnaire performed differently among the three diagnostic groups and enlightened some significant effects of gender in the expression of autistic traits.

(C) 2016 Elsevier Inc. All rights reserved.
\end{abstract}

\footnotetext{
* Corresponding author at: Department of Clinical and Experimental Medicine, University of Pisa, Via Roma 67, 56126 Pisa, Italy. Tel.: +39 050 2219766; fax: +390502219787.

E-mail address: claudia.carmassi@unipi.it (C. Carmassi).
}

\section{Introduction}

Autism has been classically described as a condition characterized by persistent impairment in reciprocal communication and social interaction, deviant development of language, and restricted, repetitive patterns of behaviors, interests or activities. 
The fourth edition of the Diagnostic and Statistical Manual of Mental Disorders (DSM-IV) [1], and its text revision version (DSM-IV-TR) [2], reunited five subcategories under the label of Pervasive Developmental Disorders, including Autistic, Asperger's, Pervasive Developmental Not Otherwise Specified, Rett and Childhood Disintegrative Disorders. The recently released DSM-5 included the former three diagnoses under the category of autism spectrum disorder (ASD), highlighting the notion that manifestations of this disorder may vary greatly depending on the degree of severity of the autistic symptomatology, on the developmental level, and chronological age, hence the term spectrum [3]. According to the DSM-5 description, in fact, some individuals with severe ASD may completely lack the faculty of speech while others might show normal formal language skills, with only impaired use of language for reciprocal communication. In addition, core diagnostic features are usually more evident in the developmental period, while interventions and learned compensation strategies may mask difficulties during adulthood. For example, certain adults with ASD may show fluent language, with relatively subtle impairment in eye contact, prosody, body posture and facial expression. Moreover, many adults with ASD with normal intelligence are able to find a niche that matches their special interests and skills providing avenues for employment and attenuating the overall impairment associated with the disorder.

Notwithstanding the fact that autism is usually recognized in early childhood, it has been reported that some ASD may reach diagnosis only in adulthood, especially when showing high levels of functioning and no language and intellectual impairment [3]. The increasing number of adult cases that has been observed in the recent years may correlate both with changes in the diagnostic criteria and with the greater awareness of autism, on which is also likely to depend the increase in the overall prevalence estimates of ASD in all age groups [4-5]. However, even when the diagnosis is delayed by the relative good levels of interpersonal and occupational functioning, people with ASD maintain a reduced ability to adapt to stressful life events and, consequently, a marked susceptibility to anxiety, mood, and trauma and stress-related disorders as well as to suicidal behaviors [6-13]. In parallel, recent literature has focused on the comorbidity between ASD and other mental disorders, with some studies raising the issue of whether psychiatric comorbidity may mask ASD, especially in subjects with normal intelligence and moderate symptoms $[7,11,12,14-16]$. The presence of undetected ASD among patients seeking for treatment for other psychiatric disorders is potentially clinically significant, since it might deserve an appropriate diagnosis and treatment. In this regard, recent literature has highlighted a possible link between ASD and eating disorders (EDs) [17-23], with some authors having even hypothesized that autistic traits may manifest as anorexia nervosa in females $[18,24,25]$. Similarly, it has been suggested that autistic traits in childhood may be a risk factor for developing EDs in adolescence [15,26-28]. A growing body of studies, in fact, has shown that also partial forms of autism and autistic traits may not only have an impact on the clinical presentation of other mental conditions, but may also play a significant role in raising the risk for some disorders as well as for suicidality $[11,29]$. This fact has increasingly highlighted the potential usefulness of careful investigations of autistic symptoms both in clinical samples and in the general population.

A significant body of studies has been drawing attention to the importance of spectrum approaches for the purpose of optimization of diagnosis and treatment of mental disorders [30-42]. In the framework of the so-called Spectrum Project, an Italian-American collaboration research project (www.spectrumproject.org), a spectrum approach has been proposed, encompassing not only core features associated with DSM mental disorders, but also isolated and atypical symptoms, as well as subthreshold symptom clusters, personality traits and behavioral manifestations that may precede, follow or be manifested in concurrence with DSM mental disorders $[30,39]$. The application of this model of spectrum provides a more accurate representation of clinical syndromes, including the recognition of subthreshold prodromal symptoms that can lead to early diagnosis and prevention [32-34,40-42].

In the last two decades, some authors have enlightened the potential usefulness of a dimensional approach in the identification of clinical endo-phenotypes to be tested in genetic research [43-45], propelling interest in the application of this approach to autistic conditions. This has led to the development of several psychometric instruments aiming to assess autistic symptoms as continuous dimensions spanning from the clinical to the non-clinical population [35-38,46,47]. Since most of the autism questionnaires based on a continuum quantitative approach were developed, some important issues have been raised regarding the definition of the core features of autism. As a matter of fact, ASD was one of the most important changes introduced with the fifth edition of the DSM, not only for the description of autism conditions as a whole, but also for a significant remodeling of symptom criteria. The DSM-IV Social and Communication domains, for example, merged into one Social-Communication domain in DSM-5, as deficits in communication were considered intimately related to social deficits. As far as the Restricted and Repetitive Interests and Behaviors domain in the DSM-5 is concerned, great importance has been devoted to the hyper-hypo reactivity to sensory inputs, for the first time included among ASD symptom criteria [3]. However, only a few items exploring this dimension are included in the existing questionnaires. Another important concern, raised by more recent literature, is that commonly used diagnostic systems are based on a male stereotype of ASD, not suitable for female manifestations of the disorder. Only in most recent years, in fact, a female profile of ASD has begun to emerge [48-52], so that it has not been yet incorporated in current nosographic systems, while currently available questionnaires may still have an over-reliance on male symptoms, and therefore not be sensitive enough to detect female-specific phenotypes of ASD. 
Aiming to address the issues raised by more recent studies, we developed the Adult Autism Subthreshold Spectrum (AdAS Spectrum), a questionnaire exploring the autism spectrum by means of 160 items in subjects with normal or above normal intelligence without language impairment. In proceeding with our conceptualization previously mentioned [30], the AdAS Spectrum refers not only to the core manifestations, but also to the attenuated and atypical symptoms, the personality traits, and the behavioral manifestations that may be associated with ASD but which may also be present in subthreshold or partial forms [53]. Further, while building the questionnaire, great attention was given to the female phenotypes of ASD as well as to the sensory reactivity area of symptoms. More specifically, most of gender-related manifestations incorporated in the questionnaire refer either to the tendency of women with ASD to camouflage by imitating others, often adopting an alternative persona and acting as someone who is socially successful, or to the proneness to avoid social interactions, choosing instead to engage in creative solitary activities, read fiction, or spend time with animals [54]. Moreover, since women with ASD have been described as showing great ability in recognizing their own social confusion so that they often try to stay on the periphery of social situations and develop intense anxiety in social situations, some social anxiety-like behavioral features have also been included in the questionnaire $[55,56]$.

The purpose of this study was to determine the psychometric properties of the AdAS Spectrum questionnaire.

\section{Methods}

The data were collected between May 2015 and April 2016 at 7 Italian University Departments of Psychiatry, coordinated by the University of Pisa: Brescia, Catania, Firenze, Napoli, Pavia and Siena.

\subsection{Study sample and procedure}

The total sample included three diagnostic groups, all evaluated according to DSM-5 criteria. Exclusion criteria were age below 18 years, language or intellectual impairment affecting the possibility to fulfill the assessments, and a diagnosis of schizophrenia. Specifically, the three groups were individuated as follows: 102 subjects endorsing at least one criterion symptom for ASD (ASDc); 143 consecutive patients attending two clinics for the treatment of feeding and eating disorders (FED); and 160 individuals without current or lifetime mental disorders (CTL). The SCID-5 was used to confirm the diagnosis of FED and the absence of mental disorders among CTL subjects, as well as to determine comorbid mental disorders in the FED and ASDc groups.

The ASDc group comprised two subgroups including: (1) 34 patients with a diagnosis of ASD (with no intellectual or language disability) recruited from a treatment program for autism (ASD); and (2) 68 subjects endorsing only one DSM-5 symptomatological criterion for ASD $\left(\mathrm{ASD}_{1}\right)$, in particular 26 subjects (38.2\%) endorsing criterion $\mathrm{A}$ and
$42(61.8 \%)$ criterion B. Since several studies have evidenced high levels of autistic traits among university students [57], $\mathrm{ASD}_{1}$ subjects were consecutively enrolled among students who responded to a recruitment campaign conducted at three University Schools in Italy (the "Scuola Superiore Sant'Anna" in Pisa, the "Collegio Universitario di Merito" in Pavia and the "Scuola Superiore di Catania" in Catania). Among ASDc subjects, none reported a DSM-5 diagnosis of FED; 2 subjects $(2.0 \%)$ reported a comorbid diagnosis of bipolar disorder (all in the $\mathrm{ASD}_{1}$ subgroup), 2 (2.0\%) a diagnosis of panic disorder (all in the $\mathrm{ASD}_{1}$ subgroup) and $29(28.4 \%)$ any other anxiety disorder (6 in the ASD subgroup and 23 in the $\mathrm{ASD}_{1}$ subgroup, respectively).

The FED group comprised two subgroups including: (1) 35 subjects who satisfied only one DSM-5 symptomatological criterion for ASD $\left(\mathrm{FED}_{1}\right)$, in particular 15 subjects $(42.9 \%)$ endorsing criterion A and 20 (57.1\%) criterion B; and (2) 108 subjects who did satisfy any DSM-5 symptomatological criterion for $\mathrm{ASD}\left(\mathrm{FED}_{0}\right)$. No FED patient reported a diagnosis of ASD. 4 subjects (2.8\%) in this group reported a comorbid diagnosis of bipolar disorder ( 1 in the $\mathrm{FED}_{0}$ subgroup and 3 in the $\mathrm{FED}_{1}$ subgroup, respectively), 8 a diagnosis of panic disorder ( 6 among $\mathrm{FED}_{0}$ and 2 among $\mathrm{FED}_{1}$ ) and 9 any other anxiety disorder (5 in the $\mathrm{FED}_{0}$ subgroup and 4 in the $\mathrm{FED}_{1}$ subgroup).

The test-retest reliability of the AdAS Spectrum, performed in order to provide evidence for the temporal stability of the AdAS Spectrum scores, was determined on 28 subjects randomly extracted from study sites, by means of a second evaluation over an interval of two weeks from the initial assessment.

The study was conducted in accordance with the Declaration of Helsinki. The Ethics Committee of the Azienda Ospedaliero-Universitaria of Pisa approved all recruitment and assessment procedures. Eligible subjects provided written informed consent, after receiving a complete description of the study and having the opportunity to ask questions. Subjects were not paid for their participation.

\subsection{Measures}

Assessment procedures included the Structured Clinical Interview for DSM-5 [58], the Autism-Spectrum Quotient (AQ) [35] the Ritvo Autism and Asperger Diagnostic Scale 14-item version (RAADS-14) [59] and the AdAS Spectrum. These assessments were conducted by psychiatrists, who were trained and certified in the use of the study instruments at the University of Pisa.

\subsubsection{The Autism-Spectrum Quotient (AQ)}

The Autism-Spectrum Quotient (AQ) is a widely used questionnaire, developed about fifteen years ago, to provide a self-report measure of autistic traits to be used in adults with normal IQ [35]. It comprises 50 questions, assessing 5 different areas: social skill, attention switching, attention to detail, communication and imagination. In the original validation study, individuals with high functioning autism were found to 
have a mean score of $35.8( \pm 6.5)$ that was significantly higher than the control group who had a mean score of $16.4( \pm 6.3)$. Test-retest and inter-rater reliability of the AQ were good, and items comprising each of the five domains showed moderate to high alpha coefficients, indicating reasonable construct validity [35]. The AQ has been used as a screening tool for ASD in the general population, as well as to evaluate autistic traits within clinical groups [12,60-64].

\subsubsection{The Ritvo Autism and Asperger Diagnostic Scale 14-item version (RAADS-14)}

The RAADS-14 [59] is a screening tool derived from the Ritvo Autism and Asperger Diagnostic Scale Revised (RAADS-R) [65] and consists of 14 questions assessing autistic symptoms. The response alternatives to each statement are given on a four-point Likert scale (ranging from 0 to 3 ) indicating the duration of each symptom $(3=$ 'true now and when I was young', 2 = 'true only now', 1 ='true only when I was younger than 16 ' and $0=$ 'never true'). In the validation paper, subjects in the ASD group showed a RAADS-14 score significantly higher than the control group, with a median score of 32 for ASD, 15 for attention deficit hyperactivity disorder, and 11 for other psychiatric disorders. A cut-off score of 14 or above reached a sensitivity of $97 \%$ and a specificity of 46 to $64 \%$. A factor analysis identified three factors consistent with mentalizing deficits, social anxiety and sensory reactivity relevant for the diagnosis of ASD.

\subsubsection{The Adult Autism Subthreshold Spectrum (AdAS Spectrum)}

The AdAS Spectrum was developed by a group of researchers from the University of Pisa, within the framework of the Spectrum Project, an international Italy-USA research network started in 1995 [32-34,39-42]. In line with all the spectrum assessment instruments, the AdAS Spectrum was developed simultaneously in Italian and English, by researchers that are essentially bilingual and some also studied in the United States (CC and CG), and revised by an Italian/ English bilingual translator that is trained in the field of psychiatry; all questions were discussed extensively, always with an eye toward deciding precisely how the concept was expressed in both languages and revised for inconsistencies between the two languages. In the present study we used the final Italian version.

The questionnaire includes 160 items exploring the wide spectrum of manifestation of autism organized into seven domains. Items responses are coded in a dichotomous way (yes/ no) and domain scores are obtained by counting the number of positive answers. The Childhood/adolescence domain describes symptoms occurring during early developmental phases, such as being very quiet or unable to speak at all, avoiding eating or playing with other children at school or being teased or bullied by schoolmates. The Verbal communication domain covers the features encompassing the tendency to not speak much or speak in a very low voice or in a strange or monotonous way, the preference for communicating via e-mail or text messages rather than speaking to someone on the phone or in person, difficulty in intervening in or ending a conversation, and the habit of butting into a conversation inopportunely. The Non-verbal communication domain explores difficulty in looking others straight in the eye, feelings of discomfort about hugging, kissing or holding someone by the hand, and tendency to take on a role to feel more at ease when interacting with other people or to flare up in a rage without reason. The Empathy domain explores impairment in understanding and interpreting the facial expressions, intentions or thoughts of others but also the presence of greater attachment to pets or objects rather than people. The Inflexibility and adherence to routine domain includes difficulty in understanding the nuances of things, difficulty in changing one's daily habits or methods of work, unwillingness to get rid of useless objects, and tendency to follow precise procedures or patterns, to write lists or to always wear the same type of clothes. The Restricted interests and rumination domain encompasses some typical symptoms such as talking only about a few preferred topics and being fascinated by numbers and systematic information about certain things, but also the proneness to brood over the same thoughts, the incapacity to be concise, and the tendency to waste time over detail, to lose track of time and to take refuge in day-dreaming. The Hyper-and hyporeactivity to sensory input explores in great details the tendency to over- or under-react to noises, textures, pain or temperature. This domain covers a broad range of manifestations, from being able to hear very low noises to perceiving noises as amplified or unbearable; from having a high pain threshold to complaining about recurrent aches; and from feeling uneasy, anxious or frightened in environments full of noise, smells and bright lights to feeling immobilized like a block of ice.

It is worth remarking that, while the AdAS Spectrum includes features belonging to ASD, it was not developed to be a diagnostic instrument. The AdAS Spectrum rather assesses the presence/absence of a broad variety of manifestations associated with ASD across the lifetime of an individual, but which may also be present in individuals who do not fulfill the diagnostic threshold, evaluated independently from their interference with the overall functioning and quality of life. From such a perspective, the duration, clustering and severity of criterion symptoms required to make a diagnosis according to the DSM-5 are not determined by means of the AdAS Spectrum. However, it allows to define, assess and test, together with the typical aspects of ASD, a wider area of clinical and non-clinical manifestations, with specific attention devoted to some gender-specific features (i.e., manifestations occurring in females that are usually under-identified due to a male-biased understanding of ASD) [66] and to hyperhypo-reactivity to sensory input, recently included as a criterion symptom in the DSM-5.

\subsection{Statistical analyses}

In order to estimate the internal consistency of the AdAS Spectrum, Kuder-Richardson coefficients were computed 
on each domain and for the total score of the questionnaire, in the total sample and by gender. In addition, Pearson's product correlation coefficients among domains were computed to explore the validity of the internal structure of the scale. The intra-class correlation coefficient (ICC) was calculated to assess the test-retest reliability of the questionnaire. The convergent validity was verified, computing Pearson's correlation coefficient between AdAS Spectrum total score and both AQ and RAADS-14 total scores, in the total sample and by gender. The Known-groups validity was determined by comparing mean total and domain scores of the AdAS Spectrum among groups. The effects of diagnosis and gender on AdAS Spectrum domain and total scores, and of their possible interactions, were analyzed by means of eight two-way ANOVA analyses. Games-Howel test, which allows for unequal variance among groups, was utilized for post-hoc pairwise comparisons. We then split the ASDc group in the ASD and $\mathrm{ASD}_{1}$ subgroups, and the FED group in the $\mathrm{FED}_{1}$ and $\mathrm{FED}_{0}$ subgroups in order to compare mean rates of endorsement of the overall scale and each domain across these five subgroups.

Further, to identify the AdAS Spectrum items that best characterize each group, the percentage of each group scoring on each item was computed.

All statistical analyses were carried out using (SPSS) version 23.0 [67].

\section{Results}

The ASDc subjects had a mean age of $24.29( \pm 8.33)$ years ( $75 \%$ of subjects were $\leq 24$ years old) and consisted of $66(64.7 \%)$ males and $36(35.3 \%)$ females. The FED subjects had a mean age of $32.73( \pm 13.06)$ years $(75 \%$ of patients were $\leq 41$ years old) and consisted of $10(7.0 \%)$ males and 132 (93.0\%) females. The group of CTL subjects, had a mean age of $26.53( \pm 9.09)$ years $(75 \%$ of subjects were $\leq 29$ years old) and consisted of 61 (38.6\%) males and 97 (61.4\%) females.

\subsection{Reliability}

Kuder-Richardson's coefficients for the overall sample and divided by gender, as well as the ICCs, evaluated in the subsample of 28 subjects, are listed in Table 1 . The reliability for the AdAS Spectrum total score was excellent, with a coefficient of .964 , in the total sample and in both gender groups. The reliability coefficients for the individual AdAS Spectrum domain scores were also high, exceeding the value of .80. Only the Empathy and Hyper-and hyporeactivity to sensory input domains showed a lower but still good level of reliability, in the total sample (.762 and .794 , respectively) and in both males (.777 and .787, respectively) and females (.755 and .795 , respectively).

The test-retest reliability for total and domain scores was found to be excellent, with all ICCs above the value of 90 .

The AdAS Spectrum domain scores were positively and significantly correlated with one another $(p<.001)$, with
Table 1

AdAS Spectrum internal consistency, in the total sample and divided by gender, and test-retest reliability.

\begin{tabular}{|c|c|c|c|c|c|}
\hline \multirow[t]{2}{*}{ AdAS Spectrum domains } & \multirow[t]{2}{*}{$\begin{array}{l}\text { Number } \\
\text { of items }\end{array}$} & \multicolumn{3}{|c|}{$\begin{array}{l}\text { Kuder-Richardson } \\
\text { coefficient }\end{array}$} & \multirow[t]{2}{*}{$\mathrm{ICC}^{\mathrm{a}}$} \\
\hline & & $\begin{array}{l}\text { Total } \\
\text { sample }\end{array}$ & Males & Females & \\
\hline Childhood/Adolescence & 21 & 0.828 & 0.808 & 0.838 & 0.984 \\
\hline Verbal communication & 18 & 0.808 & 0.817 & 0.806 & 0.941 \\
\hline Non-verbal communication & 28 & 0.808 & 0.818 & 0.807 & 0.924 \\
\hline Empathy & 12 & 0.762 & 0.777 & 0.755 & 0.976 \\
\hline $\begin{array}{l}\text { Inflexibility and adherence } \\
\text { to routine }\end{array}$ & 43 & 0.883 & 0.837 & 0.889 & 0.977 \\
\hline Restricted interest and rumination & 21 & 0.853 & 0.857 & 0.852 & 0.951 \\
\hline $\begin{array}{l}\text { Hyper- and hyporeactivity to } \\
\text { sensory input }\end{array}$ & 17 & 0.794 & 0.787 & 0.795 & 0.978 \\
\hline Total score & 160 & 0.964 & 0.964 & 0.964 & 0.976 \\
\hline
\end{tabular}

${ }^{\text {a }}$ Test-retest AdAS Spectrum reliability was determined on 28 subjects randomly extracted from study sites.

Pearson's coefficients ranging from .49 to .81 . All the AdAS Spectrum domain scores were highly correlated with the AdAS Spectrum total score (see Table 2).

\subsection{Convergent validity}

Pearson's correlation coefficients for the relationships between the AdAS Spectrum total and domain scores and alternative measures of autism spectrum symptoms are shown in Table 3. AdAS Spectrum total scores were positively and strongly correlated with both AQ and RAADS-14 total scores in the total sample ( $r=.77$ and $r=.83$, respectively) and in the two subsamples of males ( $r=.81$ and $r=.84$, respectively) and females $(r=.76$ and $r=.82$, respectively). All the AdAS Spectrum domains appeared to be from moderately to strongly correlated with AQ and RAADS-14 total scores in the total sample (Pearson's $r$ correlation coefficients ranging from .58 to .79), as well as among males (Pearson's $r$ correlation coefficients ranging from .57 to .84 ) and females (Pearson's $r$ correlation coefficients ranging from .58 to .77 ).

\subsection{Known-groups validity}

By means of eight two-way ANOVAs we explored the effects of diagnosis and gender on the AdAS Spectrum domains and total scores (Table 4a). The analyses revealed a main significant effect of the diagnosis on all the AdAS Spectrum domains and total scores (all $p<.001$ ).

As shown in Table $4 \mathrm{~b}$, the mean total and domain scores of the AdAS Spectrum were found to differ significantly across the three diagnostic groups. Post-hoc comparisons showed that the ASDc group reported significantly higher total and domain scores compared to the CTL group. The ASDc group showed significantly higher scores on the Childhood/adolescence, Verbal communication, Empathy, Inflexibility and adherence to routine and Restricted interests and rumination domains compared to the FED group. The CTL subjects displayed significantly lower total and domains scores than FED (all $p<.05$ ). 
Table 2

Correlations among the AdAS Spectrum domains ${ }^{\mathrm{a}}$.

\begin{tabular}{|c|c|c|c|c|c|c|c|}
\hline AdAS Spectrum domains & $\begin{array}{l}\text { Childhood/ } \\
\text { Adolescence }\end{array}$ & $\begin{array}{l}\text { Verbal } \\
\text { communication }\end{array}$ & $\begin{array}{l}\text { Non-verbal } \\
\text { communication }\end{array}$ & Empathy & $\begin{array}{l}\text { Inflexibility and } \\
\text { adherence to routine }\end{array}$ & $\begin{array}{l}\text { Restricted interest } \\
\text { and rumination }\end{array}$ & $\begin{array}{l}\text { Hyper-hypo reactivity } \\
\text { to sensory input }\end{array}$ \\
\hline \multicolumn{8}{|l|}{ Childhood/Adolescence } \\
\hline Verbal communication & 0.67 & & & & & & \\
\hline Non-verbal communication & 0.64 & 0.68 & & & & & \\
\hline Empathy & 0.56 & 0.61 & 0.49 & & & & \\
\hline Inflexibility and adherence to routine & 0.69 & 0,67 & 0.71 & 0.55 & & & \\
\hline Restricted interest and rumination & 0.67 & 0.75 & 0.72 & 0.56 & 0.81 & & \\
\hline $\begin{array}{l}\text { Hyper- and hyporeactivity to sensory } \\
\text { input }\end{array}$ & 0.60 & 0.66 & 0.60 & 0.52 & 0.71 & 0.72 & \\
\hline Total score & 0.82 & 0.85 & 0.84 & 0.70 & 0.91 & 0.90 & 0.81 \\
\hline
\end{tabular}

a Pearson's correlation coefficients were all significant at the $p<.001$ level, two tailed.

Further, as displayed in Table 4a, a statistically significant effect of gender emerged for the Hyper-hyporeactivity to sensory input domain of the AdAS Spectrum, with women showing higher scores than men $(3.96 \pm 3.41$ vs. $3.23 \pm 3.09$, $p=.003)$. A Diagnosis * Gender interaction was also found for the Verbal communication $(p=.019)$ and Empathy $(p=$ .023) domains. Specifically, concerning the AdAS Spectrum Verbal communication domain, among ASDc subjects, women reported statistically significant higher scores than men $(8.94 \pm 4.47$ vs. $6.98 \pm 4.14, p=.029)$ (see Fig. 1A). Concerning the Empathy domain, CTL subjects reported statistically significant lower scores with respect to either ASDc or FED among both males (2.24 \pm 2.14 vs. $4.11 \pm 3.11$, $p<.001$ and vs. $4.80 \pm 2.44, p=.017$, respectively) and females $(1.69 \pm 1.95$ vs. $5.11 \pm 3.49, p<.001$ and vs. 3.57 \pm 2.43 , $p<.001$, respectively); only among females, patients with FED reported statistically significant lower scores than ASDc subjects (3.57 \pm 2.43 vs. $5.11 \pm 3.40, p=.003$ ) (see Fig. 1B).

Splitting the ASDc group into ASD and $\mathrm{ASD}_{1}$ subgroups, and the FED into $\mathrm{FED}_{0}$ and $\mathrm{FED}_{1}$ subgroups, in order to test the AdAS Spectrum performance in detecting more subtle differences in the expression of ASD symptoms, we reported a graphical representation of the rates of endorsement in the overall AdAS Spectrum scale and each domain in the obtained five groups (Fig. 2). Statistically significant differences were obtained by means of a one-way ANOVA followed by Games-Howel tests for post-hoc comparisons. Subjects with
ASD differed from CTL, $\mathrm{FED}_{0}$ and $\mathrm{ASD}_{1}$ subjects in all AdAS domains. They also differed from $\mathrm{FED}_{1}$ in four out of seven domains (Childhood/Adolescence, Verbal communication, Empathy and Restricted interests and rumination). Concerning FED subjects, $\mathrm{FED}_{1}$ differed from $\mathrm{FED}_{0}$ and from CTL in all AdAS Spectrum domains. Moreover, they differed from $\mathrm{ASD}_{1}$ in all domains except Childhood/Adolescence and Restricted interests and rumination. $\mathrm{ASD}_{1}$ differed from CTL in all domains and from $\mathrm{FED}_{0}$ for Childhood/Adolescence and Restricted interests and rumination domains (all $p<.05$ ).

\subsection{Endorsement rates of each AdAS Spectrum item}

An item analysis (percentage in each group scoring on each item) is provided in Table 5. Percentages higher than .60 are displayed in bold.

\section{Discussion}

This paper introduces the AdAS Spectrum, a new instrument focused on a dimensional approach to autism built upon a spectrum model $[30,34]$ aiming to highlight not only the core manifestations of ASD, but also the attenuated and atypical symptoms, the personality traits, and the behavioral manifestations that may be associated with it but which may also be present in subthreshold or partial forms. Results provide evidence of the validity and reliability

Table 3

Correlations between the AdAS Spectrum domains ${ }^{\mathrm{a}}$ and AQ and RAADS-14 total score, in the total sample and divided by gender.

\begin{tabular}{|c|c|c|c|c|c|c|}
\hline \multirow[t]{2}{*}{ AdAS Spectrum domains } & \multicolumn{3}{|c|}{ AQ Total score } & \multicolumn{3}{|c|}{ RAADS-14 Total score } \\
\hline & Total sample & Males & Females & Total sample & Males & Females \\
\hline Childhood/Adolescence & 0.65 & 0.73 & 0.60 & 0.70 & 0.75 & 0.69 \\
\hline Verbal communication & 0.76 & 0.80 & 0.73 & 0.79 & 0.84 & 0.77 \\
\hline Non-verbal communication & 0.58 & 0.57 & 0.58 & 0.63 & 0.63 & 0.64 \\
\hline Empathy & 0.64 & 0.66 & 0.63 & 0.65 & 0.66 & 0.66 \\
\hline Inflexibility and adherence to routine & 0.66 & 0.74 & 0.62 & 0.71 & 0.74 & 0.70 \\
\hline Restricted interest and rumination & 0.70 & 0.73 & 0.68 & 0.72 & 0.75 & 0.70 \\
\hline Hyper- and hyporeactivity to sensory input & 0.58 & 0.58 & 0.60 & 0.70 & 0.66 & 0.71 \\
\hline Total score & 0.77 & 0.81 & 0.76 & 0.83 & 0.84 & 0.82 \\
\hline
\end{tabular}

\footnotetext{
a Pearson's correlation coefficients were all significant at the $p<.001$ level, two tailed.
} 
Table $4 \mathrm{a}$

Two-way ANOVA analyses on AdAS Spectrum domain scores.

\begin{tabular}{|c|c|c|c|c|c|c|c|c|c|}
\hline \multirow[t]{2}{*}{$\begin{array}{l}\text { Independent } \\
\text { variables }\end{array}$} & \multirow[b]{2}{*}{$d f$} & \multicolumn{2}{|c|}{$\begin{array}{l}\text { Childhood/ } \\
\text { Adolescence }\end{array}$} & \multicolumn{2}{|c|}{$\begin{array}{l}\text { Verbal } \\
\text { communication }\end{array}$} & \multicolumn{2}{|c|}{$\begin{array}{c}\text { Non-verbal } \\
\text { communication }\end{array}$} & \multicolumn{2}{|c|}{ Empathy } \\
\hline & & $F$ & $p$ & $F$ & $p$ & $F$ & $p$ & $F$ & $p$ \\
\hline Diagnosis & 2,399 & 54.39 & $<.001$ & 55.68 & $<.001$ & 38.76 & $<.001$ & 35.81 & $<.001$ \\
\hline Gender & 1,399 & 0.02 & .879 & 0.18 & .675 & 0.01 & .965 & 0.53 & .466 \\
\hline Diagnosis * Gender & 2,399 & 1.35 & .260 & 4.03 & .019 & 0.45 & .636 & 3.79 & .023 \\
\hline
\end{tabular}

\begin{tabular}{|c|c|c|c|c|c|c|c|c|c|}
\hline \multirow[t]{2}{*}{$\begin{array}{l}\text { Independent } \\
\text { variables }\end{array}$} & \multirow[b]{2}{*}{$d f$} & \multicolumn{2}{|c|}{$\begin{array}{c}\text { Inflexibility and adherence to } \\
\text { routine }\end{array}$} & \multicolumn{2}{|c|}{$\begin{array}{l}\text { Restricted interest and } \\
\text { rumination }\end{array}$} & \multicolumn{2}{|c|}{$\begin{array}{c}\text { Hyper-hypo reactivity to sensory } \\
\text { input }\end{array}$} & \multicolumn{2}{|c|}{ Total score } \\
\hline & & $F$ & $p$ & $F$ & $p$ & $F$ & $p$ & $F$ & $p$ \\
\hline Diagnosis & 2, 399 & 50.92 & $<.001$ & 62.37 & $<.001$ & 36.79 & $<.001$ & 72.94 & $<.001$ \\
\hline Gender & 1,399 & 2.92 & .088 & 3.50 & .062 & 8.63 & $.003^{\mathrm{a}}$ & 1.56 & .212 \\
\hline Diagnosis * Gender & 2, 399 & 1.61 & .201 & 1.26 & .286 & 1.92 & .148 & 2.21 & .111 \\
\hline
\end{tabular}

Bold is for statistical significance at least.

${ }^{a}$ Mean domain score in males were lower than mean domain score in females $(3.23 \pm 3.09$ vs. $3.97 \pm 3.41)$.

of the AdAS Spectrum administered to subjects with at least one DSM-5 ASD symptom criterion, to patients with FED and to healthy controls, both in the whole sample and divided by gender. We found excellent internal consistency and testretest reliability, and strong convergent validity with alternative dimensional measures of ASD. As expected, the questionnaire performed differently among the three groups explored, but it also showed good sensitivity in distinguishing subjects expressing either a full or a partial phenotype (namely, only one symptom criterion) of ASD across the three groups.

The Kuder-Richardson's coefficients showed excellent internal consistency for the AdAS Spectrum total score (.964), as well as for five out of seven domains (>.80) in the total sample. The Empathy and Hyper-and hyporeactivity to sensory input domains showed a lower but still good reliability estimate $(>.70)$. The same results were obtained when considering the male and the female subsamples separately. Likewise, the AdAS Spectrum total and domains scores showed moderate to strong positive associations with one another, confirming the validity of the internal structure of the instrument. The results of reliability analyses also provided evidence for the temporal stability of the AdAS Spectrum scores over an interval of two weeks, with excellent ICCs for the overall questionnaire and for all the domains.
The results also provided strong support for convergent validity. The AdAS Spectrum scores, in fact, showed a positive, significant correlation with alternative dimensional measures currently adopted to assess ASD symptoms and features. Particularly, all the AdAS Spectrum scores appeared to be from moderately to strongly correlated with the AQ and the RAADS-14 total scores. More specifically, moderate correlations emerged between the Non-verbal communication and the Hyper-and hyporeactivity to sensory input domains of the AdAS Spectrum and the AQ total scores, leading us to hypothesize that these could be related to the different constructs of the instruments, as the AdAS Spectrum includes a more accurate characterization of the above mentioned areas addressed by a number of specific items. Importantly, the AdAS Spectrum was shown to perform similarly in the overall sample and in both male and female subsamples separately.

Strong support was obtained for the known groups' validity of the AdAS Spectrum, as pairwise comparisons showed that subjects who met at least one DSM-5 symptom criterion for ASD scored significantly higher on the AdAS Spectrum total score compared to both patients with FED and healthy controls, confirming the discriminant validity of the questionnaire. Comparisons of the AdAS Spectrum domains scores

Table $4 \mathrm{~b}$

Main effect of diagnosis on AdAS Spectrum total and domain scores.

\begin{tabular}{|c|c|c|c|c|}
\hline AdAS Spectrum domains & $\begin{array}{l}\mathrm{CTL}(n=160) \\
(\text { mean } \pm \mathrm{SD})\end{array}$ & $\begin{array}{l}\operatorname{FED}(n=143) \\
(\text { mean } \pm \operatorname{SD})\end{array}$ & $\begin{array}{l}\operatorname{ASDc}(n=102) \\
(\text { mean } \pm \mathrm{SD})\end{array}$ & $\begin{array}{l}\text { Games-Howel post-hoc } \\
\text { comparisons }(p<.05)\end{array}$ \\
\hline Childhood/Adolescence & $4.49 \pm 3.22$ & $7.24 \pm 4.30$ & $9.70 \pm 4.53$ & $\mathrm{CTL}<\mathrm{FED}<\mathrm{ASDc}$ \\
\hline Verbal communication & $3.36 \pm 2.56$ & $5.69 \pm 3.46$ & $7.68 \pm 4.35$ & $\mathrm{CTL}<\mathrm{FED}<\mathrm{ASDc}$ \\
\hline Non-verbal communication & $6.91 \pm 4.71$ & $10.99 \pm 4.32$ & $11.84 \pm 4.97$ & $\mathrm{CTL}<\mathrm{FED}, \mathrm{CTL}<\mathrm{ASDc}$ \\
\hline Empathy & $1.91 \pm 2.04$ & $3.66 \pm 2.44$ & $4.46 \pm 3.23$ & $\mathrm{CTL}<\mathrm{FED}<\mathrm{ASDc}$ \\
\hline Inflexibility and adherence to routine & $9.33 \pm 5.95$ & $15.62 \pm 7.27$ & $17.83 \pm 7.82$ & $\mathrm{CTL}<\mathrm{FED}<\mathrm{ASDc}$ \\
\hline Restricted interest and rumination & $4.99 \pm 3.83$ & $8.16 \pm 4.33$ & $10.96 \pm 4.82$ & $\mathrm{CTL}<\mathrm{FED}<\mathrm{ASDc}$ \\
\hline Hyper- and hyporeactivity to sensory input & $2.18 \pm 2.23$ & $4.34 \pm 3.34$ & $5.24 \pm 3.72$ & $\mathrm{CTL}<\mathrm{FED}, \mathrm{CTL}<\mathrm{ASDc}$ \\
\hline Total score & $33.15 \pm 20.09$ & $55.70 \pm 23.53$ & $67.71 \pm 27.61$ & $\mathrm{CTL}<\mathrm{FED}<\mathrm{ASDc}$ \\
\hline
\end{tabular}



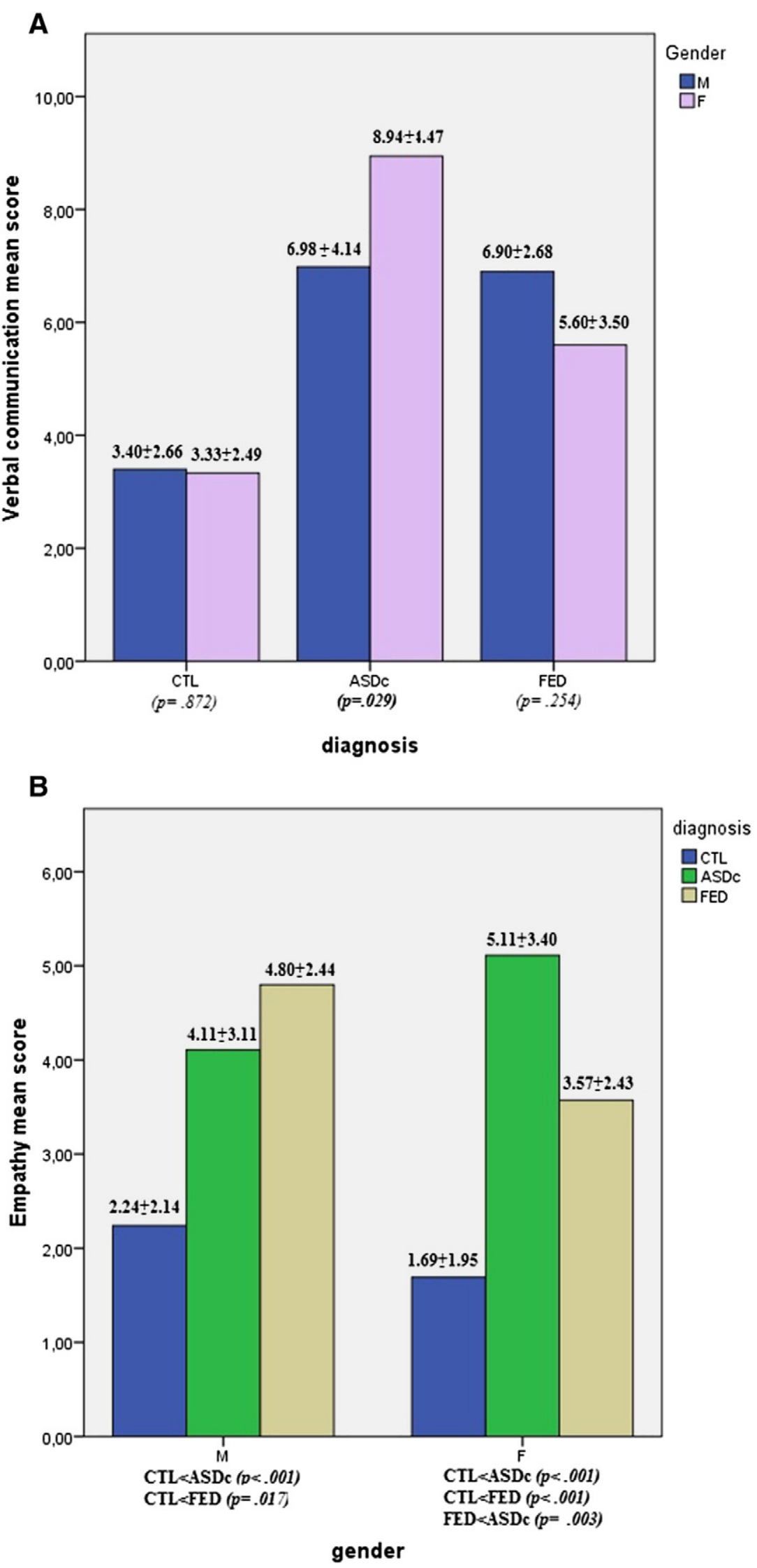

Fig. 1. (A) Gender effect on AdAS Spectrum Verbal Communication domain score in the three diagnostic groups. (B) Diagnosis effect on AdAS Spectrum Empathy domain scores among males and females. 
Mean rates of endorsement (\%)

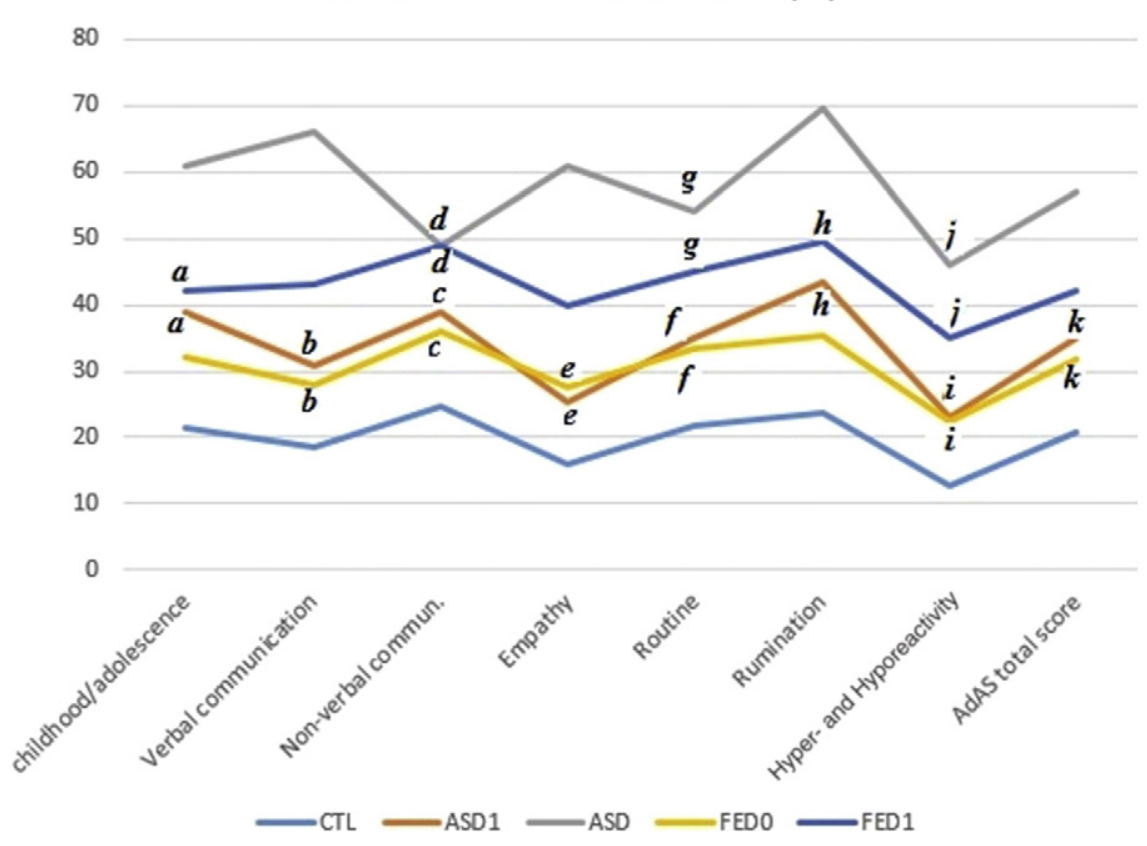

Fig. 2. Five-subgroup comparisons of AdAS Spectrum total and domain scores. Scores are expressed as percentage of items endorsed in each domain. Equal letters denote not significant differences $(p>.05)$ among the five diagnostic subgroups.

provided further information about dimensions assessed in the AdAS Spectrum. Specifically, ASDc subjects showed significantly higher scores on all AdAS Spectrum domains with respect to CTL, who, in turn, also displayed significantly lower scores than FED individuals. Even though ASDc subjects scored higher than FED patients on all domains, differences reached statistical significance in all but two domains: Non-verbal communication and Hyper-and hyporeactivity to sensory input.

The finding of higher autistic symptoms among FED patients compared to healthy controls is consistent with previous data showing high comorbidity between ASD (but also autistic traits) and EDs $[16-18,23,68,69]$. The presence of ASD symptoms, in fact, has been consistently reported in patients with EDs, especially anorexia nervosa [18-20,23,69,70]. Gillberg et al. $[19,20,70]$ first suggested a possible link between EDs and ASD as aloofness and problems with social interaction in ASD are also seen in anorexia nervosa, and the obsessive insistence on sameness in anorexia nervosa can also be seen in ASD. Moreover, consistently with the notion of possible common pathological mechanism between EDs and ASD, some reports highlight common neuropsychological traits (e.g., inflexibility, weak central coherence and executive functions in general) and behaviors (e.g., rigidity, impulsivity and poor social skills) between the two conditions [20,68,71]. Despite the fact that the question whether the autistic traits either pre-exist or follow the EDs is still unresolved $[26,68]$, underlying ASD has been suggested to significantly increase the likelihood of developing EDs $[15,16,26]$ and it has been established that autistic traits in childhood may be a risk factor for developing EDs in adolescence $[15,16,27,28,68,72]$. Thus, the AdAS Spectrum would seem to sketch a more specific picture of autism spectrum occurring in these patients characterized by deficits in non-verbal communication and disordered reactivity to sensory input, which are the two dimensions that did not show to significantly differentiate FED subjects from ASDc.

Notably, our results seem to suggest the ability of the AdAS Spectrum to detect a different expression of sensory reactivity between gender groups, with females showing higher scores on the Hyper-and hyporeactivity to sensory input domain across the three diagnostic groups. Even though preliminary, these results seem to corroborate scant previous observations concerning the possible female phenotype of Asperger's Disorder $[54,55]$. We may also argue that two further results of this study support the possible usefulness of the AdAS Spectrum in detecting gender-related dimensions of autism spectrum. First, males were shown to better perform in verbal communication than female counterparts only in the ASDc group. Previous literature insights indicate that male subjects with ASD exhibit poorer verbal abilities than female counterparts [73]; however, somehow in keeping with our results, another study revealed that girls with high autistic symptoms but without a diagnosis of ASD show greater communication difficulties than males, despite reduced social impairment [74]. Second, while CTL group showed lower impairment in empathic function than FED and ASDc in both male and female subgroups, a significant difference in empathy between FED and ASDc was also found only among women.

With the aim of testing the sensitivity of AdAS Spectrum in detecting more subtle differences in the expression of ASD symptoms, the ASDc group was further divided into patients with ASD and subjects with one ASD symptom criterion $\left(\mathrm{ASD}_{1}\right)$, and the FED group in patients with or without one 
Table 5

Item analysis: rates of endorsement (\%) by groups.

\begin{tabular}{|c|c|c|c|c|c|c|c|}
\hline Item & $\begin{array}{l}\text { CTL } \\
(n=160)\end{array}$ & $\begin{array}{l}\text { FED } \\
(n=143)\end{array}$ & $\begin{array}{l}\text { ASDc } \\
(n=103)\end{array}$ & Item & $\begin{array}{l}\text { CTL } \\
(n=160)\end{array}$ & $\begin{array}{l}\text { FED } \\
(n=143)\end{array}$ & $\begin{array}{l}\text { ASDc } \\
(n=103)\end{array}$ \\
\hline 1 & 16.3 & 25.9 & 46.1 & 81 & 15.6 & 26.6 & 43.1 \\
\hline 2 & 15.0 & 34.3 & 54.9 & 82 & 7.5 & 9.8 & 21.6 \\
\hline 3 & 33.1 & 44.8 & 66.7 & 83 & 20.0 & 26.6 & 36.3 \\
\hline 4 & 21.9 & 21.0 & 67.6 & 84 & 29.4 & 48.3 & 31.4 \\
\hline 5 & 18.8 & 41.3 & 59.8 & 85 & 25.0 & 47.6 & 52.0 \\
\hline 6 & 27.5 & 41.3 & 46.1 & 86 & 26.3 & 46.9 & 62.7 \\
\hline 7 & 26.9 & 41.3 & 36.3 & 87 & 11.9 & 16.8 & 33.3 \\
\hline 8 & 45.0 & 59.4 & 69.6 & 88 & 26.9 & 46.9 & 45.1 \\
\hline 9 & 26.3 & 33.6 & 57.8 & 89 & 13.8 & 31.5 & 30.4 \\
\hline 10 & 1.9 & 17.5 & 22.5 & 90 & 16.9 & 34.3 & 41.2 \\
\hline 11 & 17.5 & 32.9 & 36.3 & 91 & 3.1 & 23.1 & 18.6 \\
\hline 12 & 4.4 & 20.3 & 27.5 & 92 & 19.4 & 14.0 & 46.1 \\
\hline 13 & 18.8 & 18.2 & 42.2 & 93 & 10.0 & 13.3 & 33.3 \\
\hline 14 & 21.3 & 53.1 & 63.7 & 94 & 22.5 & 21.0 & 54.9 \\
\hline 15 & 13.1 & 37.1 & 44.1 & 95 & 49.4 & 51.0 & 51.0 \\
\hline 16 & 48.8 & 49.7 & 70.6 & 96 & 13.8 & 20.3 & 47.1 \\
\hline 17 & 31.9 & 45.5 & 44.1 & 97 & 59.4 & 69.9 & 75.7 \\
\hline 18 & 23.8 & 43.4 & 36.3 & 98 & 55.0 & 76.2 & 73.5 \\
\hline 19 & 28.7 & 44.1 & 58.8 & 99 & 42.5 & 58.7 & 67.6 \\
\hline 20 & 5.6 & 7.7 & 11.8 & 100 & 11.9 & 29.4 & 25.5 \\
\hline 21 & 2.5 & 12.6 & 6.9 & 101 & 19.4 & 53.1 & 45.1 \\
\hline 22 & 11.9 & 26.6 & 31.4 & 102 & 8.1 & 21.0 & 17.6 \\
\hline 23 & 15.0 & 38.5 & 46.1 & 103 & 3.1 & 11.9 & 11.8 \\
\hline 24 & 25.0 & 42.7 & 52.9 & 104 & 22.5 & 58.0 & 53.9 \\
\hline 25 & 21.9 & 36.4 & 53.9 & 105 & 28.7 & 64.3 & 57.8 \\
\hline 26 & 15.6 & 27.3 & 30.4 & 106 & 3.1 & 7.0 & 0.0 \\
\hline 27 & 16.3 & 20.3 & 46.1 & 107 & 13.8 & 31.5 & 33.3 \\
\hline 28 & 8.8 & 10.5 & 28.4 & 108 & 24.4 & 46.2 & 52.0 \\
\hline 29 & 16.3 & 51.7 & 50.0 & 109 & 23.8 & 45.5 & 54.9 \\
\hline 30 & 0.6 & 9.1 & 18.6 & 110 & 12.5 & 46.2 & 39.2 \\
\hline 31 & 6.3 & 13.3 & 21.6 & 111 & 24.4 & 38.5 & 46.1 \\
\hline 32 & 9.4 & 23.8 & 40.2 & 112 & 22.5 & 46.2 & 49.0 \\
\hline 33 & 65.6 & 54.5 & 77.5 & 113 & 38.8 & 43.4 & 46.1 \\
\hline 34 & 13.8 & 29.4 & 47.1 & 114 & 23.1 & 23.8 & 26.5 \\
\hline 35 & 35.0 & 49.7 & 51.0 & 115 & 13.1 & 30.1 & 26.5 \\
\hline 36 & 9.4 & 26.6 & 21.6 & 116 & 6.9 & 24.5 & 21.6 \\
\hline 37 & 18.8 & 27.3 & 47.1 & 117 & 8.8 & 37.1 & 38.2 \\
\hline 38 & 28.7 & 49.7 & 56.9 & 118 & 15.6 & 25.2 & 33.3 \\
\hline 39 & 17.5 & 32.2 & 47.1 & 119 & 60.0 & 71.3 & 84.3 \\
\hline 40 & 62.5 & 79.0 & 66.7 & 120 & 8.1 & 21.7 & 23.5 \\
\hline 41 & 19.4 & 42.7 & 45.1 & 121 & 19.4 & 28.0 & 39.2 \\
\hline 42 & 15.0 & 37.1 & 37.3 & 122 & 25.6 & 34.3 & 39.2 \\
\hline 43 & 33.8 & 37.1 & 34.3 & 123 & 12.5 & 15.4 & 23.5 \\
\hline 44 & 32.5 & 53.8 & 49.0 & 124 & 10.0 & 21.0 & 30.4 \\
\hline 45 & 7.5 & 21.0 & 27.5 & 125 & 48.1 & 61.5 & 62.7 \\
\hline 46 & 33.1 & 63.6 & 57.8 & 126 & 8.1 & 25.9 & 36.3 \\
\hline 47 & 41.3 & 50.3 & 41.2 & 127 & 16.9 & 30.8 & 52.0 \\
\hline 48 & 24.4 & 21.7 & 39.2 & 128 & 23.8 & 40.6 & 57.8 \\
\hline 49 & 20.6 & 32.2 & 61.8 & 129 & 18.8 & 31.5 & 55.9 \\
\hline 50 & 15.6 & 36.4 & 24.5 & 130 & 15.6 & 39.2 & 45.1 \\
\hline 51 & 27.5 & 55.9 & 39.2 & 131 & 31.3 & 54.5 & 64.7 \\
\hline 52 & 23.1 & 54.5 & 59.8 & 132 & 17.5 & 18.2 & 40.2 \\
\hline 53 & 20.6 & 29.4 & 46.1 & 133 & 8.1 & 14.7 & 40.2 \\
\hline 54 & 30.0 & 49.0 & 48.0 & 134 & 21.3 & 33.6 & 61.8 \\
\hline 55 & 34.4 & 39.9 & 56.9 & 135 & 19.4 & 25.9 & 54.9 \\
\hline 56 & 21.3 & 30.8 & 33.3 & 136 & 19.4 & 34.3 & 44.1 \\
\hline 57 & 15.6 & 48.3 & 44.1 & 137 & 21.3 & 26.6 & 33.3 \\
\hline 58 & 49.4 & 59.4 & 53.9 & 138 & 48.8 & 74.8 & 80.4 \\
\hline 59 & 17.5 & 37.8 & 39.2 & 139 & 28.1 & 56.6 & 67.6 \\
\hline 60 & 14.4 & 27.3 & 43.1 & 140 & 36.9 & 55.9 & 70.6 \\
\hline 61 & 10.6 & 14.0 & 19.6 & 141 & 36.9 & 55.2 & 56.9 \\
\hline
\end{tabular}

Table 5 (continued)

\begin{tabular}{llllllll}
\hline Item & $\begin{array}{l}\text { CTL } \\
(n=160)\end{array}$ & $\begin{array}{l}\text { FED } \\
(n=143)\end{array}$ & $\begin{array}{l}\text { ASDc } \\
(n=103)\end{array}$ & $\begin{array}{l}\text { Item } \\
\text { CTL } \\
(n=160)\end{array}$ & $\begin{array}{l}\text { FED } \\
(n=143)\end{array}$ & $\begin{array}{l}\text { ASDc } \\
(n=103)\end{array}$ \\
\hline 62 & 25.0 & 43.4 & 43.1 & 142 & 22.5 & 51.7 & 52.0 \\
63 & 8.1 & 21.7 & 18.6 & 143 & 33.8 & 48.3 & $\mathbf{6 5 . 7}$ \\
64 & 16.9 & 25.2 & 35.3 & 144 & 18.8 & 25.2 & 51.0 \\
65 & 49.4 & 57.3 & $\mathbf{7 0 . 6}$ & 145 & 23.8 & 32.9 & 45.1 \\
66 & 16.9 & 19.6 & 39.2 & 146 & 2.5 & 9.1 & 12.7 \\
67 & 4.4 & 11.2 & 9.8 & 147 & 13.1 & 27.3 & 31.4 \\
68 & 12.5 & 42.0 & 24.5 & 148 & 10.6 & 23.1 & 30.4 \\
69 & 3.8 & 13.3 & 31.4 & 149 & 20.6 & 32.2 & 51.0 \\
70 & 24.4 & 45.5 & 34.3 & 150 & 17.5 & 33.6 & 26.5 \\
71 & 26.3 & 30.1 & 54.9 & 151 & 19.4 & 38.5 & 32.4 \\
72 & 12.5 & 24.5 & 38.2 & 152 & 5.0 & 17.5 & 15.7 \\
73 & 13.1 & 23.8 & 45.1 & 153 & 6.3 & 19.6 & 19.6 \\
74 & 8.1 & 23.8 & 18.6 & 154 & 18.1 & 24.5 & 42.2 \\
75 & 9.4 & 25.2 & 23.5 & 155 & 3.8 & 28.0 & 19.6 \\
76 & 31.3 & 37.1 & 55.9 & 156 & 23.1 & 42.0 & 36.3 \\
77 & 18.1 & 29.4 & 31.4 & 157 & 11.3 & 27.3 & 43.1 \\
78 & 11.9 & 28.7 & 35.3 & 158 & 3.8 & 11.9 & 6.9 \\
79 & 19.4 & 42.7 & 52.9 & 159 & 16.9 & 23.8 & 39.2 \\
80 & 26.9 & 41.3 & 53.9 & 160 & 3.8 & 17.5 & 20.6 \\
\hline
\end{tabular}

ASD symptom criterion $\left(\mathrm{FED}_{1}\right.$ and $\left.\mathrm{FED}_{0}\right)$. Results showed a gradient of severity in AdAS Spectrum scores from CTL subjects to ASD patients, across $\mathrm{FED}_{0}, \mathrm{ASD}_{1}, \mathrm{FED}_{1}$. These results support of the existence of a continuous distribution of autism dimensions spanning from ASD-affected subjects to the general population and spreading across different disorders $[30,35,75-78]$. This might also suggest the need for assessing subthreshold autism spectrum in other mental disorders.

When examining these results, potential limitations of the study should be acknowledged. First of all, the age distribution within the three diagnostic groups, with most subjects in the younger age ranges, impaired us performing a more detailed investigation of the possible role of age as independent variable interacting with both diagnosis and gender. Further studies in larger samples stratified by different age ranges are thus warranted. However, it is important to notice that the AdAS Spectrum is a lifetime instrument that captures symptoms that may arise anytime across the lifespan, with the only exception of the domain referring to childhood and adolescence. Second, our findings did not elucidate whether this continuum is uni- or multidimensional because of the relatively small sample size that prevented us from performing a factor analysis. Third is the fact that the AdAS Spectrum is a self-report instrument and it may be considered less accurate compared to the rating of the clinician. Fourth, the questionnaire is quite long. However, in this regard, it has to be noted that the great number of items allowed us to depict some subtle differences in the way in which subjects with ASD, even in its subthreshold forms, and those with FED express autistic symptoms.

In the context of the above-mentioned limitations, the AdAS Spectrum displayed good psychometric properties. Overall, the dimensions explored by the AdAS Spectrum seem to be relevant for patients with ASD, either with sub-threshold or full-blown disorder, and proved to constitute a robust construct. The number of items and the content of AdAS 
Spectrum could help in solving some of the shortcomings of the DSM-5 conceptualization of ASD and existing instruments by giving a more specific description of the clinical phenotype of each patient, with important implications for research and, ultimately, for professionals' awareness of autistic conditions. The evidence of a specific profile in patients with FED, while not enabling us to draw definitive conclusions, suggested that the AdAS Spectrum might be a promising instrument to use in different samples, which may help to identify specific phenotypes to be used in clinical, neurobiological and genetic studies.

\section{Conclusions}

The results of the present study show a coherent construct of the AdAS Spectrum with high internal consistency, sound test-retest reliability, and strong convergent validity with alternative dimensional measures of autism. Further studies are warranted to test this new tool not only in ASD patients, including those featuring partial and sub-threshold forms, but also in different diagnostic groups and in the general population.

\section{Acknowledgment and funding sources}

The study was supported by the European Project TRIGGER (Transforming Institutions by Gendering Contents and Gaining Equality in Research - Grant agreement no. 611034). We are also grateful to Paolo Davide D'Arienzo and to the Scuola Superiore Sant'Anna for the valuable contribution made toward this research.

\title{
1. Appendix
}

\section{AdAS Spectrum}

\begin{abstract}
Subject
ID:

Date:

Instructions: The following questions refer to feelings or experiences you may have had in the past or that you may be experiencing currently. Please answer each of the questions by circling "YES" or "NO." Please note that not all the questions refer to symptoms of an illness.
\end{abstract}

CHILDHOOD/ADOLESCENCE

\begin{tabular}{|c|c|c|c|}
\hline \multicolumn{4}{|c|}{ When you were a child: } \\
\hline 1 & $\begin{array}{l}\text { did gestures of affection (caresses, hugs, kisses) from relatives or friends ever } \\
\text { make you feel uneasy? }\end{array}$ & YES & NO \\
\hline 2 & $\begin{array}{l}\text { did you ever make a series of rituals before going to sleep (for example, placing } \\
\text { shoes, clothes, books or toys in a particular position), saying goodnight or } \\
\text { praying in a particular way, or did you have to listen to a certain story? }\end{array}$ & YES & NO \\
\hline 3 & $\begin{array}{l}\text { were you ever extremely careful about your school books, exercise books or } \\
\text { toys and did not like others to borrow or even touch them? }\end{array}$ & YES & NO \\
\hline 4 & $\begin{array}{l}\text { did you ever devote most of your free time to isolated activities (e.g., } \\
\text { videogames or books, etc.)? }\end{array}$ & YES & NO \\
\hline 5 & did you have few friends? & YES & NO \\
\hline 6 & were you always in search of the ideal friend? & YES & NO \\
\hline 7 & $\begin{array}{l}\text { were you very possessive of your friends, seeking an exclusive relationship } \\
\text { with them? }\end{array}$ & YES & NO \\
\hline 8 & were you an obstinate, stubborn child? & YES & NO \\
\hline 9 & did you particularly love to collect objects? & YES & NO \\
\hline 10 & $\begin{array}{l}\text { at school did you ever avoid eating or playing or doing gymnastics with other } \\
\text { children? }\end{array}$ & YES & NO \\
\hline 11 & $\begin{array}{l}\text { did you ever suffer from head-aches or stomach-aches in social situations or at } \\
\text { the thought of having to face social situations? }\end{array}$ & YES & NO \\
\hline
\end{tabular}




\begin{tabular}{|c|l|c|c|}
\hline 12 & would you have preferred not to go to school, and study at home alone? & YES & NO \\
\hline 13 & $\begin{array}{l}\text { were you ever extremely selective in your friendships, considering almost all } \\
\text { other children to be unintelligent and/or too superficial? }\end{array}$ & YES & NO \\
\hline 14 & $\begin{array}{l}\text { was it ever difficult for you to establish new friendships, take part in a group, } \\
\text { play team-games? }\end{array}$ & YES & NO \\
\hline 15 & were you very quiet and sometimes unable to speak at all? & YES & NO \\
\hline 16 & $\begin{array}{l}\text { do you remember, or has anyone ever described you as being talented in } \\
\text { particular fields }(e . g ., \text { music, mathematics, chess) }\end{array}$ & YES & NO \\
\hline 17 & $\begin{array}{l}\text { do you remember, or has anyone ever told you, that you were talented in some } \\
\text { fields but that you performed poorly in others? }\end{array}$ & YES & NO \\
\hline 18 & did you ever try to avoid performing in public? & YES & NO \\
\hline 19 & were you ever teased by school-mates or bullied? & YES & NO \\
\hline 20 & have you ever bullied anyone or been cruel to animals or weaker companions? & YES & NO \\
\hline 21 & did you call your parents by name instead of calling them "mom" and "dad"? & YES & NO \\
\hline
\end{tabular}

VERBAL COMMUNICATION

\begin{tabular}{|c|l|c|c|}
\hline \multicolumn{2}{|l|}{ The following questions refer to feelings or experiences you may have had during your life } & YES & NO \\
\hline 22 & Do you tend to not speak much and/or use very short sentences? & YES & NO \\
\hline 23 & $\begin{array}{l}\text { Do you usually speak in a very low voice or in too loud a voice, or in a strange } \\
\text { or monotonous way? }\end{array}$ & YES & NO \\
\hline 24 & $\begin{array}{l}\text { Do you ever say what you think, only to understand later that you have } \\
\text { offended someone? }\end{array}$ & YES & NO \\
\hline 25 & $\begin{array}{l}\text { Has it ever been pointed out that you make inopportune statements and/or } \\
\text { behave in a unusual or odd way? }\end{array}$ & YES & NO \\
\hline 26 & $\begin{array}{l}\text { Does it often happen that you don't get jokes? } \\
\text { Have you ever noticed, or has anyone ever pointed out that other people do not } \\
\text { find funny or are not impressed by the jokes you like? }\end{array}$ & YES & NO \\
\hline
\end{tabular}




\begin{tabular}{|c|c|c|c|}
\hline 28 & Do you tend to repeat jokes, even though they make no-one laugh? & YES & NO \\
\hline 29 & Are you given to taking things literally? & YES & NO \\
\hline 30 & $\begin{array}{l}\text { Do you have difficulty in immediately grasping the broad sense of a certain } \\
\text { expressions (for example, "a hen-pecked husband", "a face like the back of a } \\
\text { bus")? }\end{array}$ & YES & NO \\
\hline 31 & $\begin{array}{l}\text { Does the expression "put yourself in my shoes", especially if coming from a } \\
\text { person of the opposite sex, make you laugh or seem totally meaningless to you? }\end{array}$ & YES & NO \\
\hline 32 & Do you have difficulty in ending a conversation once started? & YES & NO \\
\hline 33 & Do you ever quote phrases heard in films or read in books? & YES & NO \\
\hline 34 & Do you find it hard to intervene in a conversation? & YES & NO \\
\hline 35 & Is speaking in public particularly stressful for you? & YES & NO \\
\hline 36 & Do you absolutely avoid speaking in public? & YES & NO \\
\hline 37 & Do you ever butt into a conversation inopportunely? & YES & NO \\
\hline 38 & Do you ever talk to yourself, asking and answering questions? & YES & NO \\
\hline 39 & $\begin{array}{l}\text { Do you distinctly prefer communicating via e-mail or text messages rather than } \\
\text { speak to someone on the phone or in person? }\end{array}$ & YES & NO \\
\hline
\end{tabular}

\section{NON VERBAL COMMUNICATION}

\begin{tabular}{|c|l|c|c|}
\hline 40 & Do you feel uncomfortable if someone looks at you insistently? & YES & NO \\
\hline 41 & $\begin{array}{l}\text { Do you have difficulty looking others straight in the eye or not know where to } \\
\text { look when talking to someone? }\end{array}$ & YES & NO \\
\hline 42 & Have you ever been arrogant in order to hide your insecurity? & YES & NO \\
\hline 43 & Have you ever dreamed of being naked? & YES & NO \\
\hline 44 & Are you considered a very touchy person? & YES & NO \\
\hline
\end{tabular}




\begin{tabular}{|c|c|c|c|}
\hline 45 & $\begin{array}{l}\text { Are you the sort of person who does not worry about maintaining friendships or } \\
\text { sentimental relationships? }\end{array}$ & YES & NO \\
\hline 46 & Do you tend to hunch your shoulders and bow your head? & YES & NO \\
\hline 47 & $\begin{array}{l}\text { Do you regret not knowing how to dance elegantly and without feeling } \\
\text { inhibited? }\end{array}$ & YES & NO \\
\hline 48 & Are you good at taking off acquaintances or famous people? & YES & NO \\
\hline 49 & $\begin{array}{l}\text { Do you ever take on a role to feel more at ease when interacting with other } \\
\text { people? }\end{array}$ & YES & NO \\
\hline 50 & $\begin{array}{l}\text { Have you ever used alcohol, anxiolytics or drugs to get over a disappointment } \\
\text { or failure, or in order to help you face an important event? }\end{array}$ & YES & NO \\
\hline 51 & Have you ever flared up in a rage without reason? & YES & NO \\
\hline 52 & $\begin{array}{l}\text { Do you feel more at ease without people around you at work or in a private } \\
\text { setting? }\end{array}$ & YES & NO \\
\hline 53 & $\begin{array}{l}\text { Have you ever thought that certain situations can influence other ones, even if } \\
\text { totally unconnected, (for example, "If I put my left foot down first when I get } \\
\text { out of bed, it'll be a nice day")? }\end{array}$ & YES & NO \\
\hline 54 & $\begin{array}{l}\text { Do you envy successful people, leaders or those who are generally approved of } \\
\text { by others? }\end{array}$ & YES & NO \\
\hline 55 & Do you often invent excuses or even tell lies in unimportant situations? & YES & NO \\
\hline 56 & $\begin{array}{l}\text { Have you ever invented a situation or a story in order to put yourself in a better } \\
\text { light? }\end{array}$ & YES & NO \\
\hline 57 & $\begin{array}{l}\text { Do you have difficulty in doing even simple things if someone is watching you } \\
\text { (such as talking on the phone, eating or writing? }\end{array}$ & YES & NO \\
\hline 58 & $\begin{array}{l}\text { When you have to do something in public, (for example, speaking), do you } \\
\text { have to be absolutely perfectly prepared? }\end{array}$ & YES & NO \\
\hline
\end{tabular}




\begin{tabular}{|c|c|c|c|}
\hline 59 & At work do you often say you are busy even when you have nothing to do? & YES & NO \\
\hline 60 & $\begin{array}{l}\text { Do you feel uneasy about hugging, kissing or holding someone you like by the } \\
\text { hand? }\end{array}$ & YES & NO \\
\hline 61 & In general, do you like being naked at home or going to nudist camps? & YES & NO \\
\hline 62 & Do you avoid taking up sentimental relationships for fear of being rejected? & YES & NO \\
\hline 63 & $\begin{array}{l}\text { Is it easier for you to have sexual intercourse rather than get involved in an } \\
\text { intimate emotional relationship with a partner? }\end{array}$ & YES & NO \\
\hline 64 & $\begin{array}{l}\text { Do you often fantasize about or have you ever been involved in non- } \\
\text { conventional or illicit sexual relationships? }\end{array}$ & YES & NO \\
\hline 65 & Do you prefer to not confide in anyone regarding your most intimate thoughts? & YES & NO \\
\hline 66 & $\begin{array}{l}\text { Do you spend a lot of time playing videogames or surfing on internet, to the } \\
\text { extent of forgetting to do routine tasks? }\end{array}$ & YES & NO \\
\hline 67 & $\begin{array}{l}\text { Do you like role-playing so much that you identify yourself with your character } \\
\text { to the point of living a second life? }\end{array}$ & YES & NO \\
\hline
\end{tabular}

\section{EMPATHY}

\begin{tabular}{|c|c|c|c|}
\hline 68 & Have you ever felt more attached to your pet than to other people? & YES & NO \\
\hline 69 & Have you ever felt much more attached to an object than to other people? & YES & NO \\
\hline 70 & $\begin{array}{l}\text { Have you ever been involved in impossible sentimental relationships or with } \\
\text { people already involved with others or who are much younger/older than you? }\end{array}$ & YES & NO \\
\hline 71 & $\begin{array}{l}\text { Have you ever been told that you are rather inhibited, or cold or too detached } \\
\text { towards others? }\end{array}$ & YES & NO \\
\hline \multicolumn{4}{|c|}{ Is it difficult for you: } \\
\hline 72 & identifying with someone else? & YES & $\mathrm{NO}$ \\
\hline
\end{tabular}




\begin{tabular}{|c|l|c|c|}
\hline 73 & understanding the intentions or thoughts of the person in front of you? & YES & NO \\
\hline 74 & identifying with the protagonists of a book or film, and feeling what they feel? & YES & NO \\
\hline 75 & understanding the intentions of the characters in a book or a film? & YES & NO \\
\hline 76 & understanding when someone is flirting with you? & YES & NO \\
\hline 77 & understanding if someone is interested in or bored by what you are saying? & YES & NO \\
\hline 78 & interpreting the facial expressions and body language of others? & YES & NO \\
\hline 79 & imagining what others expect from you? & YES & NO \\
\hline
\end{tabular}

\section{INFLEXIBILITY AND ADHERENCE TO ROUTINE}

\begin{tabular}{|c|l|c|c|}
\hline 80 & $\begin{array}{l}\text { Do you have difficulty in getting rid of useless objects such as used-up pens or } \\
\text { newspapers that have been read? }\end{array}$ & YES & NO \\
\hline 81 & Do you collect objects of value as well as useless things? & YES & NO \\
\hline 82 & $\begin{array}{l}\text { Do you feel compelled to finish a collection once you have started it? } \\
\text { There is an object that you would never separate from and that you want to } \\
\text { carry with you all the time? }\end{array}$ & YES & NO \\
\hline 83 & $\begin{array}{l}\text { Are you excessively careful about aesthetical aspects (for example, matching } \\
\text { colours, taste in clothes or furnishing?) }\end{array}$ & YES & NO \\
\hline 85 & $\begin{array}{l}\text { Have you ever felt compelled to repeat a certain action (like wringing your } \\
\text { hands, twisting an object or a lock of hair between your fingers) or say certain } \\
\text { words without any precise reason? }\end{array}$ & YES & NO \\
\hline 86 & $\begin{array}{l}\text { Have you ever felt compelled to repeat (even only mentally) a word or phrase } \\
\text { that particularly struck you? }\end{array}$ & YES & NO \\
\hline 87 & Have you ever felt compelled to walk in a particular way? & YES \\
\hline 85 & No & YES \\
\hline 8
\end{tabular}




\begin{tabular}{|c|c|c|c|}
\hline 89 & Do you tend to control every movement of your body? & YES & NO \\
\hline 90 & $\begin{array}{l}\text { Have you ever felt compelled to clear your throat before speaking or make } \\
\text { certain movements with your hands before writing or knocking on the door? }\end{array}$ & YES & NO \\
\hline 91 & $\begin{array}{l}\text { Have you ever felt the need to repeatedly clean some areas of the house while } \\
\text { neglecting others, e.g., meticulously cleaning the sink but overlooking the rest } \\
\text { of the bathroom? }\end{array}$ & YES & NO \\
\hline 92 & $\begin{array}{l}\text { Are you particularly irritated by the use of certain popular words or catch- } \\
\text { phrases like "Bob's your uncle!", "Cheerio" or "Well, I never!" ? }\end{array}$ & YES & NO \\
\hline 93 & $\begin{array}{l}\text { Are there any vowels or consonants or certain numbers that you particularly } \\
\text { dislike? }\end{array}$ & YES & NO \\
\hline 94 & Are you in the habit of inventing words and puns? & YES & NO \\
\hline 95 & $\begin{array}{l}\text { When you are telling a joke, do you alter your voice and accent according to the } \\
\text { character? }\end{array}$ & YES & NO \\
\hline 96 & $\begin{array}{l}\text { When you are subject to a lot of stress, can you calm yourself down by making } \\
\text { circular movements or by rocking yourself on a chair? }\end{array}$ & YES & NO \\
\hline 97 & Do you need to think about something carefully before making a decision? & YES & NO \\
\hline 98 & At work, do you prefer to follow precise procedures or patterns? & YES & NO \\
\hline 99 & Are you headstrong and always do things your way? & YES & NO \\
\hline 100 & Do you always wear the same type of clothes? & YES & NO \\
\hline 101 & $\begin{array}{l}\text { Do you rarely make changes to your aims in life even when it would be } \\
\text { advisable to do so? }\end{array}$ & YES & NO \\
\hline 102 & Do you have to make a list of the things to do every day? & YES & NO \\
\hline 103 & $\begin{array}{l}\text { Do you write lists to remember the principles you want to follow or behaviour } \\
\text { you want to adopt? }\end{array}$ & YES & NO \\
\hline 104 & Are you unsettled by unexpected events (for example, last-minute invitations)? & YES & NO \\
\hline
\end{tabular}




\begin{tabular}{|c|c|c|c|}
\hline 105 & Are you not really willing to change your daily habits? & YES & NO \\
\hline 106 & $\begin{array}{l}\text { Do you have sexual intercourse following precise routines (e.g., only on certain } \\
\text { days of the week, in certain places or at certain times)? }\end{array}$ & YES & NO \\
\hline 107 & $\begin{array}{l}\text { Do you have difficulty in changing your mind about something even in front of } \\
\text { evidence to the contrary? }\end{array}$ & YES & $\mathrm{NO}$ \\
\hline 108 & $\begin{array}{l}\text { Have you often had difficulty in changing your way of reacting and/or your } \\
\text { methods of working even when there might be a better approach? }\end{array}$ & YES & NO \\
\hline 109 & Have you often had difficulty in adapting to the different characters of people? & YES & NO \\
\hline 110 & $\begin{array}{l}\text { Have you often had difficulty in understanding the nuances of things, tending } \\
\text { instead to be categorically 'black or white', 'all-or-nothing', 'good or bad'? }\end{array}$ & YES & NO \\
\hline 111 & $\begin{array}{l}\text { Have you often had difficulty in lending or borrowing clothes, books, records } \\
\text { or other personal objects? }\end{array}$ & YES & NO \\
\hline 112 & $\begin{array}{l}\text { Have you often felt the need to impose your ways of doing things and your } \\
\text { habits on friends and family members (for example, your idea of cleanliness, } \\
\text { your routines)? }\end{array}$ & YES & NO \\
\hline 113 & $\begin{array}{l}\text { Are you the type of person who is not prepared to compromise with regard to } \\
\text { moral questions? }\end{array}$ & YES & NO \\
\hline 114 & Are you very observant of the rules of etiquette? & YES & NO \\
\hline 115 & Are you particularly fascinated by military parades or uniforms? & YES & NO \\
\hline 116 & $\begin{array}{l}\text { Are you one of those people who has to have everything in the house, or in the } \\
\text { office, always in exactly the same place? }\end{array}$ & YES & NO \\
\hline 117 & $\begin{array}{l}\text { Have you ever been aggressive because other people wanted to stop you from } \\
\text { carrying out your rituals or because they did not let you have your own way? }\end{array}$ & YES & NO \\
\hline 118 & $\begin{array}{l}\text { If you notice something wrong, even if it does not concern you directly, do you } \\
\text { feel obliged to intervene (e.g., writing to the newspapers or on Facebook)? }\end{array}$ & YES & NO \\
\hline
\end{tabular}




\begin{tabular}{|c|l|c|c|}
\hline 119 & Do you tend to get irritated when you lose things you are fond of? & YES & NO \\
\hline 120 & Have you ever been told you behave too formally and stand on ceremony? & YES & NO \\
\hline 121 & $\begin{array}{l}\text { Have you ever thought that to get along well with other people there should be } \\
\text { a precise set of rules to respect? }\end{array}$ & YES & NO \\
\hline 122 & $\begin{array}{l}\text { Do you have difficulty in changing your opinion about someone you hold very } \\
\text { much in esteem, despite proof of his/her unreliability? }\end{array}$ & YES & NO \\
\hline
\end{tabular}

\section{RESTRICTED INTERESTS AND RUMINATION}

\begin{tabular}{|c|c|c|c|}
\hline 123 & $\begin{array}{l}\text { Do you particularly admire one or more famous celebrities (collecting posters, } \\
\text { gadgets, photos and interviews)? }\end{array}$ & YES & NO \\
\hline 124 & Do you like talking only to people who share your same specific interests? & YES & NO \\
\hline 125 & $\begin{array}{l}\text { Are you particularly good at picking up detail (e.g., parts of objects, parts of the } \\
\text { body etc.)? }\end{array}$ & YES & NO \\
\hline 126 & Do you like to think and talk only about the few things that interest you? & YES & NO \\
\hline 127 & $\begin{array}{l}\text { Do you try to avoid social occasions (e.g., dinners, parties, weddings, etc.) } \\
\text { because you consider them to be a waste of time, and because you feel uneasy } \\
\text { with people who talk about trivial things? }\end{array}$ & YES & NO \\
\hline 128 & $\begin{array}{l}\text { Do you sometimes have a thought or a topic fixed in your mind to the point that } \\
\text { you cannot stop talking about it even when others do not seem at all interested? }\end{array}$ & YES & NO \\
\hline 129 & $\begin{array}{l}\text { Is it rare for you to find the topics preferred by most other people interesting or } \\
\text { appealing? }\end{array}$ & YES & NO \\
\hline 130 & $\begin{array}{l}\text { Do you have the impression your thoughts are stored in your memory as if they } \\
\text { were indexed in an archive? }\end{array}$ & YES & NO \\
\hline 131 & $\begin{array}{l}\text { Does it often happen that you are absorbed in something to the point of } \\
\text { completely losing track of everything else? }\end{array}$ & YES & NO \\
\hline
\end{tabular}




\begin{tabular}{|c|c|c|c|}
\hline 132 & $\begin{array}{l}\text { Are you fascinated by numbers (e.g., dates, car registration plates, public } \\
\text { transport time-tables etc.)? }\end{array}$ & YES & NO \\
\hline 133 & $\begin{array}{l}\text { Do you like to collect systematic information about certain things (e.g., types of } \\
\text { cars, aeroplanes, trains, plants or animals)? }\end{array}$ & YES & NO \\
\hline 134 & $\begin{array}{l}\text { Do you tend to have very strong interests and does it bother you deeply if you } \\
\text { cannot pursue them? }\end{array}$ & YES & NO \\
\hline 135 & Do you always try to put your reasoning or your observations in order? & YES & NO \\
\hline 136 & $\begin{array}{l}\text { Have you ever been described as or have you ever considered yourself to be } \\
\text { someone with little capacity to be concise in your work or study as you tend to } \\
\text { waste time over detail? }\end{array}$ & YES & NO \\
\hline 137 & Do you regularly arrive late for appointments because you lose track of time? & YES & NO \\
\hline 138 & Do you tend to brood over the same matters or the same thoughts? & YES & NO \\
\hline 139 & $\begin{array}{l}\text { Do your thoughts often take up all your attention, leaving you unable to do } \\
\text { anything else? }\end{array}$ & YES & NO \\
\hline 140 & $\begin{array}{l}\text { Do you often continue to ponder over things even in the case of problems } \\
\text { which do not have an answer? }\end{array}$ & YES & NO \\
\hline 141 & Do you often have difficulty in falling asleep because you cannot stop thinking? & YES & NO \\
\hline 142 & $\begin{array}{l}\text { Do you insist on a particular way of doing things, taking up more time than } \\
\text { would be normal to complete a task, and you are never satisfied with the result? }\end{array}$ & YES & NO \\
\hline 143 & Do you often take refuge in fantasizing or day-dreaming? & YES & NO \\
\hline
\end{tabular}

HYPER- AND HYPOREACTIVITY TO SENSORY INPUT

\begin{tabular}{|c|l|c|c|}
\hline 144 & $\begin{array}{l}\text { Have you ever perceived buzzing or low noises to be amplified or even } \\
\text { unbearable? }\end{array}$ & YES & NO \\
\hline 145 & Have you ever seen indistinct and threatening images in the shadows? & YES & NO \\
\hline
\end{tabular}




\begin{tabular}{|c|c|c|c|}
\hline 146 & $\begin{array}{l}\text { Have you heard other people's voices become suddenly strange and } \\
\text { frightening? }\end{array}$ & YES & $\mathrm{NO}$ \\
\hline 147 & $\begin{array}{l}\text { While awake, have you ever felt strange, inexplicable sensations on your skin } \\
\text { and in your body (e.g. the feeling of being touched, or wet or run through by an } \\
\text { electric current)? }\end{array}$ & YES & NO \\
\hline 148 & $\begin{array}{l}\text { While awake, have you ever perceived noises, or odours or flavours that no-one } \\
\text { else could perceive? }\end{array}$ & YES & NO \\
\hline 149 & Do you avoid passing through or stopping in noisy places? & YES & NO \\
\hline 150 & $\begin{array}{l}\text { Do you think you have a low pain threshold, for example when you get injured } \\
\text { or cut? }\end{array}$ & YES & NO \\
\hline 151 & $\begin{array}{l}\text { Do you think you have a high pain threshold, for example when you get injured } \\
\text { or cut? }\end{array}$ & YES & NO \\
\hline 152 & $\begin{array}{l}\text { Have you ever suffered from aches for which you referred to physicians but for } \\
\text { which nobody was able to find a cause? }\end{array}$ & YES & NO \\
\hline 153 & $\begin{array}{l}\text { Do you sometimes shut yourself away in total darkness because the light even } \\
\text { though barely filtering through closed shutters unsettles your mood and/or } \\
\text { concentration? }\end{array}$ & YES & NO \\
\hline 154 & $\begin{array}{l}\text { Have you ever been convinced that you possess unusual abilities or that you } \\
\text { have had particularly unusual experiences? }\end{array}$ & YES & $\mathrm{NO}$ \\
\hline 155 & $\begin{array}{l}\text { Is the physical sensation of food in your mouth more important than the actual } \\
\text { taste? }\end{array}$ & YES & NO \\
\hline 156 & Are some common fabrics unpleasant or irritating to you on your skin? & YES & NO \\
\hline 157 & $\begin{array}{l}\text { If you find yourself in an environment full of noise, smells and bright lights, do } \\
\text { you feel uneasy, anxious or frightened? }\end{array}$ & YES & NO \\
\hline 158 & $\begin{array}{l}\text { Have you ever happened to feel immobilized, like a block of ice, without being } \\
\text { able to respond to being called for hours or days? }\end{array}$ & YES & NO \\
\hline 159 & Do you happen to hear also low noises which other people cannot hear? & YES & $\mathrm{NO}$ \\
\hline 160 & $\begin{array}{l}\text { Do you sometimes have difficulty in washing and need to be prompted to do } \\
\text { so? }\end{array}$ & YES & $\mathrm{NO}$ \\
\hline
\end{tabular}

\section{References}

[1] American Psychiatric Association. Diagnostic and statistical manual of mental disorders. 4th ed. (DSM-IV). Washington, DC: APA; 1994.

[2] American Psychiatric Association. Diagnostic and statistical manual of mental disorders. 4th edition, text revision (DSM-IV-TR). Washingtong, DC: APA; 2000

[3] American Psychiatric Association. Diagnostic and statistical manual of mental disorders. 5th ed. (DSM-5). Arlington, VA: APA; 2013.

[4] Brugha TS, McManus S, Bankart J, Jenkins R, Smith J, Scott F. The proportion of true cases of autism is not changing. Br Med $\mathrm{J}$ 2014;348:g3774.

[5] Christensen DL, Baio J, Braun KV, Bilder D, Charles J, Constantino $\mathrm{JN}$, et al. Prevalence and characteristics of autism spectrum disorder among children aged 8 years - autism and developmental disabilities monitoring network, 11 sites, United States, 2012. MMWR Surveill Summ 2016;65:1-23.

[6] Dell'Osso L, Dalle Luche R, Carmassi C. A new perspective in posttraumatic stress disorder: which role for unrecognized autism spectrum? Emerg Ment Health 2015;17.

[7] Dell'Osso L, Dalle Luche R, Cerliani C, Bertelloni CA, Gesi C, Carmassi C. Unexpected subthreshold autism spectrum in a 25 -yearold male stalker hospitalized for delusional disorder: a case report. Compr Psychiatry 2015;61:10-4.

[8] Simoncini M, Miniati M, Vanelli F, Callari A, Vannucchi G, Mauri M, et al. Lifetime autism spectrum features in a patient with a psychotic mixed episode who attempted suicide. Case Rep Psychiatry 2014;2014:1-4.

[9] Lugnegard T, Hallerback MU, Gillberg C. Psychiatric comorbidity in young adults with a clinical diagnosis of Asperger syndrome. Res Dev Disabil 2011;32:1910-7. 
[10] Hofvander B, Delorme R, Chaste P, Nyden A, Wentz E, Stahlberg O, et al. Psychiatric and psychosocial problems in adults with normalintelligence autism spectrum disorders. BMC Psychiatry 2009;9:35.

[11] Takara K, Kondo T. Autism spectrum disorder among first-visit depressed adult patients: diagnostic clues from backgrounds and past history. Gen Hosp Psychiatry 2014;36:737-42.

[12] Mito H, Matsuura N, Mukai K, Yanagisawa Y, Nakajima A, Motoyama M, et al. The impacts of elevated autism spectrum disorder traits on clinical and psychosocial features and long-term treatment outcome in adult patients with obsessive-compulsive disorder. Compr Psychiatry 2014;55:1526-33.

[13] Sierro G, Rossier J, Mohr C. Validation of the French Autism Spectrum Quotient scale and its relationships with schizotypy and Eysenckian personality traits. Compr Psychiatry 2016;68:147-55.

[14] Yirmiya N, Shaked M. Psychiatric disorders in parents of children with autism: a meta-analysis. J Child Psychol Psychiatry 2005;46:69-83.

[15] Jacobi C, Agras WS, Bryson S, Hammer LD. Behavioral validation, precursors, and concomitants of picky eating in childhood. J Am Acad Child Adolesc Psychiatry 2003;42:76-84.

[16] Karjalainen L, Gillberg C, Rastam M, Wentz E. Eating disorders and eating pathology in young adult and adult patients with ESSENCE. Compr Psychiatry 2016;66:79-86.

[17] Huke V, Turk J, Saeidi S, Kent A, Morgan JF. Autism spectrum disorders in eating disorder populations: a systematic review. Eur Eat Disord Rev 2013;21:345-51.

[18] Koch SV, Larsen JT, Mouridsen SE, Bentz M, Petersen L, Bulik C, et al. Autism spectrum disorder in individuals with anorexia nervosa and in their first- and second-degree relatives: Danish nationwide register-based cohort-study. Psychiatry 2015;206:401-7.

[19] Gillberg C. Autism and anorexia nervosa: related conditions? Nord Psykiatr Tidsskr 1985;39:307-12.

[20] Gillberg IC, Billstedt E, Wentz E, Anckarsäter H, Råstam M, Gillberg C. Attention, executive functions, and mentalizing in anorexia nervosa eighteen years after onset of eating disorder. J Clin Exp Neuropsychol 2010;32:358-65.

[21] Courty A, Maria A, Lalanne C, Ringuenet D, Vindreau C, Chevallier $\mathrm{C}$, et al. Levels of autistic traits in anorexia nervosa: a comparative psychometric study. BMC Psychiatry 2013;13:222.

[22] Baron-Cohen S, Jaffa T, Davies S, Auyeung B, Allison C, Wheelwright S. Do girls with anorexia nervosa have elevated autistic traits? Mol Autism 2013;4:24.

[23] Tchanturia K, Smith E, Weineck F, Fidanboylu E, Kern N, Treasure J, et al. Exploring autistic traits in anorexia: a clinical study. Mol Autism 2013;4:44

[24] Morgan J, Huke V. Faculty of 1000 evaluation for do girls with anorexia nervosa have elevated autistic traits? F1000 - post-publication peer review of the biomedical literature: faculty of 1000, Ltd; 2013.

[25] Zucker NL, Losh M, Bulik CM, LaBar KS, Piven J, Pelphrey KA. Anorexia nervosa and autism spectrum disorders: guided investigation of social cognitive endophenotypes. Psychol Bull 2007;133:976-1006.

[26] Kalyva E. Comparison of eating attitudes between adolescent girls with and without Asperger syndrome: daughters' and mothers' reports. J Autism Dev Disord 2008;39:480-6.

[27] Anckarsäter H, Hofvander B, Billstedt E, Gillberg IC, Gillberg C, Wentz E, et al. The sociocommunicative deficit subgroup in anorexia nervosa: autism spectrum disorders and neurocognition in a community-based, longitudinal study. Psychol Med 2011;42:1957-67.

[28] Wentz E, Gillberg IC, Anckarsater H, Gillberg C, Rastam M. Adolescentonset anorexia nervosa: 18-year outcome. Psychiatry 2009;194:168-74.

[29] Kato K, Mikami K, Akama F, Yamada K, Maehara M, Kimoto K, et al. Clinical features of suicide attempts in adults with autism spectrum disorders. Gen Hosp Psychiatry 2013;35:50-3.

[30] Frank E, Cassano GB, Shear MK, Rotondo A, Dell'Osso L, Mauri M, et al. The spectrum model: a more coherent approach to the complexity of psychiatric symptomatology. CNS Spectr 1998;3:23-34.

[31] Frank E, Cassano GB, Michelin S, Shear MK, Coli E, Maser J, et al. Co-morbidity, co-occurrence, or confusion: can we articulate a more coherent model for describing the complexity of psychiatric symptomatology? Biol Psychiatry 1997;42:132S.

[32] Dell'Osso L, Armani A, Rucci P, Frank E, Fagiolini A, Corretti G, et al. Measuring mood spectrum: comparison of interview (SCI-MOODS) and self-report (MOODS-SR) instruments. Compr Psychiatry 2002;43:69-73.

[33] Cassano GB, Banti S, Mauri M, Dell'Osso L, Miniati M, Maser JD, et al. Internal consistency and discriminant validity of the Structured Clinical Interview for Panic Agoraphobic Spectrum (SCI-PAS). Methods Psychiatr Res 1999;8:138-45.

[34] Cassano GB, Dell'Osso L, Frank E, Miniati M, Fagiolini A, Shear K, et al. The bipolar spectrum: a clinical reality in search of diagnostic criteria and an assessment methodology. J Affect Disord 1999;54:319-28.

[35] Baron-Cohen S, Wheelwright S, Skinner R, Martin J, Clubley E. The autism-spectrum quotient (AQ): evidence from Asperger syndrome/highfunctioning autism, males and females, scientists and mathematicians. J Autism Dev Disord 2001;31:5-17.

[36] Bölte S, Poustka F, Constantino JN. Assessing autistic traits: crosscultural validation of the social responsiveness scale (SRS). Autism Res 2008;1:354-63.

[37] Bölte S. Brief report: the Social Responsiveness Scale for Adults (SRS-A): initial results in a German cohort. J Autism Dev Disord 2011;42:1998-9.

[38] Wheelwright S, Auyeung B, Allison C, Baron-Cohen S. Defining the broader, medium and narrow autism phenotype among parents using the Autism Spectrum Quotient (AQ). Mol Autism 2010;1:10.

[39] Frank E, Shear MK, Rucci P, Banti S, Mauri M, Maser JD, et al. Crosscultural validity of the structured clinical interview for panic-agoraphobic spectrum. Soc Psychiatry Psychiatr Epidemiol 2005 Apr;40(4):283-90.

[40] Dell'Osso L, Carmassi C, Rucci P, Conversano C, Shear MK, Calugi $\mathrm{S}$, et al. A multidimensional spectrum approach to post-traumatic stress disorder: comparison between the Structured Clinical Interview for Trauma and Loss Spectrum (SCI-TALS) and the self-report instrument (TALS-SR). Compr Psychiatry 2009;50:485-90.

[41] Dell'Osso L, Shear MK, Carmassi C, Rucci P, Maser JD, Frank E, et al. Validity and reliability of the Structured Clinical Interview for the Trauma and Loss Spectrum (SCI-TALS). Clin Pract Epidemiol Ment Health 2008;4:2.

[42] Dell'Osso L, Rucci P, Cassano GB, Maser JD, Endicott J, Shear MK, et al. Measuring social anxiety and obsessive-compulsive spectra: comparison of interviews and self-report instruments. Compr Psychiatry 2002;43:81-7.

[43] Leboyer M, Bellivier F, Nosten-Bertrand M, Jouvent R, Pauls D, Mallet J. Psychiatric genetics: search for phenotypes. Trends Neurosci 1998;21:102-5.

[44] Losh M, Sullivan PF, Trembath D, Piven J. Current developments in the genetics of autism: from phenome to genome. J Neuropathol Exp Neurol 2008;67:829-37.

[45] Picardi A, Fagnani C, Medda E, Toccaceli V, Brambilla P, Stazi MA. Genetic and environmental influences underlying the relationship between autistic traits and temperament and character dimensions in adulthood. Compr Psychiatry 2015;58:178-88.

[46] Costantino JN. The Social Responsiveness Scale. Los Angeles: Western Psychological Services; 2002.

[47] Dawson G, Estes A, Munson J, Schellenberg G, Bernier R, Abbott R. Quantitative assessment of autism symptom-related traits in probands and parents: Broader Phenotype Autism Symptom Scale. J Autism Dev Disord 2006;37:523-36.

[48] Auyeung B, Taylor K, Hackett G, Baron-Cohen S. Foetal testosterone and autistic traits in 18 to 24-month-old children. Mol Autism 2010;1:11

[49] Baron-Cohen S, Cassidy S, Auyeung B, Allison C, Achoukhi M, Robertson S, et al. Attenuation of typical sex differences in 800 adults with autism vs. 3,900 controls. PLoS One 2014;9:e102251.

[50] Lai M-C, Baron-Cohen S, Buxbaum JD. Understanding autism in the light of sex/gender. Mol Autism 2015;6.

[51] Lai M-C, Lombardo MV, Auyeung B, Chakrabarti B, Baron-Cohen S. Sex/gender differences and autism: setting the scene for future research. J Am Acad Child Adolesc Psychiatry 2015;54:11-24.

[52] Lombardo MV, Ashwin E, Auyeung B, Chakrabarti B, Lai M-C, Taylor K, et al. Fetal programming effects of testosterone on the 
reward system and behavioral approach tendencies in humans. Biol Psychiatry 2012;72:839-47.

[53] Dell'Osso L, Dalle Luche R, Maj M. Adult autism spectrum as a transnosographic dimension. CNS Spectr 2015;21:131-3.

[54] Attwood T, Grandin T, Faherty C, Bolick T, Iland L, Snyder R, et al. Asperger's and girls. Arlington, TX: Future Horizons; 2006.

[55] Attwood T. The pattern of abilities and development for girls with Asperger's syndrome. In Asperger's and girls. eds. Arlington, TX: Future Horizons Inc.; 2006.

[56] Clark J. Asperger's in pink: pearls of wisdom from inside the bubble of raising a child with Asperger's. Arlington, TX: Future Horizons; 2010.

[57] Pisula E, Kawa R, Szostakiewicz Ł, Łucka I, Kawa M, Rynkiewicz A. Autistic traits in male and female students and individuals with high functioning autism spectrum disorders measured by the Polish Version of the Autism-Spectrum Quotient. PLoS One 2013;8:e75236.

[58] First MB, Williams JB, Karg RS, Spitzer RL. SCID-5-CV: Structured Clinical Interview for DSM-5 Disorders; clinician version. American Psichiatric Association Publishing; 2015.

[59] Eriksson JM, Andersen LMJ, Bejerot S. RAADS-14 screen: validity of a screening tool for autism spectrum disorder in an adult psychiatric population. Mol Autism 2013;4:49.

[60] Cath DC, Ran N, Smit JH, van Balkom AJLM, Comijs HC. Symptom overlap between autism spectrum disorder, generalized social anxiety disorder and obsessive-compulsive disorder in adults: a preliminary case-controlled study. Psychopathology 2007;41:101-10.

[61] Hoekstra RA, Bartels M, Cath DC, Boomsma DI. Factor structure, reliability and criterion validity of the Autism-Spectrum Quotient (AQ): a study in Dutch population and patient groups. J Autism Dev Disord 2008;38:1555-66.

[62] Mealey A, Abbott G, Byrne LK, McGillivray J. Overlap between autistic and schizotypal personality traits is not accounted for by anxiety and depression. Psychiatry Res 2014;219:380-5.

[63] Spek AA, Wouters SGM. Autism and schizophrenia in high functioning adults: behavioral differences and overlap. Res Autism Spectr Disord 2010;4:709-17.

[64] Wouters SGM, Spek AA. The use of the Autism-Spectrum Quotient in differentiating high-functioning adults with autism, adults with schizophrenia and a neurotypical adult control group. Res Autism Spectr Disord 2011;5:1169-75

[65] Ritvo RA, Ritvo ER, Guthrie D, Ritvo MJ, Hufnagel DH, McMahon W, et al. The Ritvo Autism Asperger Diagnostic Scale-Revised
(RAADS-R): a scale to assist the diagnosis of autism spectrum disorder in adults: an international validation study. J Autism Dev Disord 2010;41:1076-89.

[66] Rynkiewicz A, Schuller B, Marchi E, Piana S, Camurri A, Lassalle A, et al. An investigation of the 'female camouflage effect' in autism using a computerized ADOS-2 and a test of sex/gender differences. Mol Autism 2016;7.

[67] Armonk NIC. IBM SPSS statistics for windows, version 23.0. IBM Corp; 2015

[68] Carton AM, Smith AD. Assessing the relationship between eating disorder psychopathology and autistic traits in a non-clinical adult population. Eat Weight Disord 2014;19:285-93.

[69] Mandy W, Tchanturia K. Do women with eating disorders who have social and flexibility difficulties really have autism? A case series. Mol Autism 2015;6:6.

[70] Gillberg C, Råstam M. Do some cases of anorexia nervosa reflect underlying autistic-like conditions? Behav Neurol 1992;5:27-32.

[71] Treasure J. Coherence and other autistic spectrum traits and eating disorders: building from mechanism to treatment. The Birgit Olsson lecture. Psychiatry 2013;67:38-42.

[72] Jobe LE, Williams WS. Loneliness, social relationships, and a broader autism phenotype in college students. Personal Individ Differ 2007:42:1479-89.

[73] Lai MC, Lombardo MV, Pasco G, Ruigrok ANV, Wheelwright SJ, Sadek SA, et al. A behavioral comparison of male and female adults with high functioning autism spectrum conditions. PLoS One 2011;6(6):e20835.

[74] Dworzynsky K, Ronald A, Bolton P, Happé F. How different are girls and boys above and below the diagnostic threshold for autism spectrum disorders? J Am Acad Child Adolesc Psychiatry 2012;51(8):788-97.

[75] Wing L. Asperger's syndrome: a clinical account. Psychol Med $1981 ; 11: 115-29$

[76] Wing L. The continuum of autistic characteristics. Diagnosis and assessment in autism. Springer Science + Business Media; 198891-110.

[77] Frith U, Morton J, Leslie AM. The cognitive basis of a biological disorder: autism. Trends Neurosci 1991;14:433-8.

[78] Billeci L, Calderoni S, Conti E, Gesi C, Carmassi C, Dell'Osso L, et al The broad autism (Endo)phenotype: neurostructural and neurofunctional correlates in parents of individuals with autism spectrum disorders. Front Neurosci 2016;10:346. 